\title{
JUDICIAL NOTICE AND DEPOSITION PRACTICE IN INTERNATIONAL LITIGATION
}

\author{
In view of statutory innovations in the areas of judicial notice of \\ foreign law and depositions taken abroad, and the practical diffi- \\ culties encountered under these statutes, this comment attempts \\ a reevaluation of modern trends and needs.
}

$P_{\text {Leading, proof, and the just, effective utilization of foreign law in }}$ local courts, has always been a subject of interest to practitioners and scholars alike. ${ }^{1}$ The taking of depositions in foreign countries for use locally is of equal interest. It is the purpose of this comment to undertake a general survey of the state legislation ${ }^{2}$ and the newly

${ }^{1}$ The literature in the field is extensive. See generally Sommerich \& Buscil, Foreign Law: A Guide to Pleading and Proof (1959); Currie, On the Displacement of the Law of the Forum, 58 CoLUM. L. REv. 964 (1958); Miller, International Cooperation in Litigation Between the United States and Switzerland: Unilateral Procedural Accommodation in a Test Tube, 49 MrN. L. Rev. 1069 (1965); Nussbaum, Proving the Law of Foreign Countries, 3 AM. J. CoMp. L. 60 (1954); Nussbaum, The Problem of Proving Foreign Law, 50 YALE L.J. 1018 (1941). Relevant sources may also be found in Miller, supra at 1106 n.122.

2 State rather than federal law has been chosen for various reasons. A large percentage of the cases in the area come from the state courts, and the mere multiplicity of state laws offers a greater spectrum of procedures from which salutary provisions may be noted. It has also been suggested that the procedure utilized in international litigation in American courts has been developed almost exclusively by the state courts. See Jones, International Judicial Assistance: Procedural Chaos and a Program for Reform, 62 YALE L.J. 515, 542 (1953).

It should, however, be noted that the 1964 proposed amendments, reprinted in 34 F.R.D. 325 (1964) and 249 F.Supp. No. 4 (1966) [subsequent citations to the proposed amendments shall be to 34 F.R.D.], to the Federal Rules of Civil Procedurc, effective July 1, 1966, do contain a provision relating to the "Determination of Foreign Law." Proposed rule 44.1 states: "A party who intends to raise an issue concerning the law of a foreign country shall give notice in his pleadings or other reasonable written notice. The court, in determining foreign law, may consider any relevant material or source, including testimony, whether or not submitted by a party or admissible under Rule 43. The court's determination shall be treated as a ruling on a question of law." 34 F.R.D. 325, 402 (1964). (Italics omitted.)

Since the federal rule is based on the research done by the Commission and Advisory Committee on International Rules of Judicial Procedure, the Advisory Committee on Civil Rules, and the Columbia Law School Project on International Procedure, it is extremely similar to the Unifora INTERstate AND INTERnational ProCEDURE ACT art. IV, which was also promulgated by that Commission. See note 12 infra. The only difference between proposed rule 44.1 and the uniform act would seem to be that the former does not state that the court, rather than the jury, shall determine the tenor of foreign law. The Advisory Committee intimated that this was simply due to the fact that the Federal Rules of Civil Procedure do not treat the area of allocation of functions between the court and jury. Advisory Committee's Note, 34 F.R.D. at 403 .

It should also be noted that the 1964 proposed Rules of Criminal Procedure, 
formulated uniform laws relevant to these evidentiary matters, with a view toward evaluating the degree to which such laws facilitate the expeditious and fair disposition of international litigation.

\section{I}

\section{Judicial Notice of Foreign Law}

The evidentiary device of judicial notice allows a court to consider certain readily verifiable facts which have not been presented to it under the formal rules of evidence. Through frequent statutory innovations, judicial notice has been used to eliminate the characteristic formality that accompanied common law pleading and proving of foreign law. ${ }^{3}$ It is, however, necessary to become familiar with the situation at common law in order to more fully understand and evaluate any statutory changes in the field.

Under the common law, the law of sister states and foreign countries was treated as a question of fact which had to be pleaded and proved. ${ }^{4}$ An obvious consequence of this treatment of foreign law as "fact" was that the jury rather than the court was required to consider and determine the specific tenor of the law. ${ }^{5}$ Where proof of the foreign law was insufficient, courts often indulged in the use

reprinted in 34 F.R.D. 411 (1964), contain a provision, proposed rule 26.1, id. at 433-34, almost identical to proposed civil rule 44.1. It is questionable whether, in light of rule 44.1, this proposed rule for criminal procedure is really necessary. However, the Advisory Committee has indicated several areas where it feels a rule specifically aimed at determination of foreign criminal law is requisite. "Problems of foreign law that must be resolved in accordance with the Federal Rules of Criminal Procedure are most likely to arise in places such as Washington, D.C., the Canal Zone, Guam, and the Virgin Islands, where the federal courts have general criminal jurisdiction. ... [I]n an extradition proceeding, reasonable ground to believe that the person sought to be extradited is charged with, or was convicted of, a crime under the laws of the demanding state must generally be shown. ... [See Factor v. Laubenheimer, 290 U.S. 276 (1933)]." Advisory Committee's Note, supra at 434. The note goes on to point out that the tenor of foreign law may be relevant in order to justify non-compliance with a subpoena duces tecum, see Application of Chase Manhattan Bank, 297 F.2d 611 (2d Cir. 1962), and also in proceedings arising under 18 U.S.C. § 1201 (1964) (transportation in kidnapping cases), and 18 U.S.C. \$§ 2312-17 (1964) (transportation of stolen property). Advisory Committee's Note, supra at 434 .

${ }^{3}$ See generally McCoRmick, Evmence $\S 323-31$ (1954).

- See Cuba R.R. v. Crosby, 222 U.S. 473 (1912). See generally Sommerich \& Busch, op. cit. supra note 1 , at 1l-17; 9 Wigmore, Evidence $\S 2573$ (3d ed. 1940).

Dyer v. Smith, 12 Conn. 384 (1837); Thompson v. Ketchum, 8 Jons. R. 146 (N.Y. 1811). It has been suggested that the older cases often distinguished between instances where the foreigu law was proven by means of witnesses on the one hand and by foreign statutes and case law on the other. If the former mode of proof was employed, the foreigu law was considered a question of fact; if the latter, it was deemed a question of law for the court. Annot., 34 A.L.R. 1447, 1464 (1925). 
of various presumptions as to the content of foreign law ${ }^{0}$ which, although allowing a court to dispose of a particular case, were not always solidly based in logic. This system produced such anomalous results ${ }^{\top}$ that the need for reform became evident. The device of judicial notice seemed to provide the answer and, beginning with Massachusetts in 1926, ${ }^{\circ}$ almost all states developed statutes which apply judicial notice to at least some areas of foreign law. ${ }^{9}$ However, these statutes developed rather haphazardly and as a consequence, various uniform acts were drafted with a view toward uniform state treatment of the foreign law problem. Among these acts are the Uniform Judicial Notice of Foreign Law Act, ${ }^{10}$ the Uniform

${ }^{6}$ For a full discussion of the various presumptions used, see Annot, 75 A.L.R.2d 529 (1961). Briefly, these presumptions included the following: certain fundamental principles are common to all civilized legal systems; foreign law is the same as the law of the forum; the law of the forum applies without indulging in any presumption; the common law is presumed applicable. A classic enumeration of these presumptions may be found in Leary v. Gledhill, 8 N.J. 260, 266.67, 84 A.2d 725, 728 (1951). Without the utilization of such presumptions, the reliance on foreign law was a dangerous proposition, and the lack of sufficient proof could render valid claims unenforceable. Cf. Cuba R.R. v. Crosby, 222 U.S. 473 (1912).

Presumptions may still play an important part in the contemporary law. For example, the California statute provides that if the foreign law cannot be ascertained the action may either be dismissed or shall proceed with California law being applied. Cal. Civ. Proc. Code $\S 1875$ (Supp. 1965). Thus, the California statute may be viewed as in essence analogous to a common law presumption that the law of the forum is the same as the forcign law.

"If the foreign law was treated as a fact, a complaint which failed to plead the foreign law was subject to dismissal. "Proving" foreign law was often extremely diffcult and costly under the technical rules of proof since a party was frequently forced to present the fact-finders with expert witnesses and translations of foreign statutes and court decisions. Further, once the jury had determined the foreign law in question, their finding was not subject to appellate review; nor was it given stare decisis effect. Most unusual of all was the paradoxical situation created wherein a true question of law was to be decided by fact-finders. See Stern, Foreign Law in the Courts: Judicial Notice and Proof, 45 CALIF. L. REv. 23, 24-29 (1957).

${ }^{8}$ Mass. ANN. Laws ch. 233, $\$ 70$ (1956).

- Most jurisdictions have enacted statutes pertaining in some degree to judicial notice of foreign country law: ARK. STAT. ANN. $\$ 27.2504$ (Supp. 1965); CAL. Crv. Proc. Code $\S 1875$ (Supp. 1965), to be replaced by CaL. Evidence Code $\$ \$ 310-11$, 450-60 (effective Jan. 1, 1967); CoNN. GEN. STAT. ANN. \$\$ 52-163 to -164 (1960); KaN. Gen. Stat. AnN. \$ 60-409 (1964); Md. ANn. Code art. 35, $\$ 47$ (1965); Mass. AnN. LAws ch. 233, $\$ 70$ (1956); Mich. STAT. ANN. $\S \S 27 A .2114,27 A .2118$ (1962); Miss. CODE ANN. § 1761 (1956); N.J. STAT. ANN. § 2A:82-27 (Supp. 1965); N.Y.R. Crv. Prac. 4511; N.C. Gen. STAT. \$ 8-4 (1953); Okla. Laws 1965, ch. 144, at 168; VA. CODE ANN. § 8-273 (1957); V.I. CoDE tit. 5, $\$ \S 4926-28$ (Supp. 1965).

${ }^{10}$ In 1936 the Conference of Commissioners on Uniform Laws approved the Uniform Judicial Notice of Foreign Law Act. A copy of the act may be found in $9 A$ UNIFORM LAwS ANN. 553 (1965). Section 5 of the act, however, speciflcally exempts foreign country law from judicial notice treatment. 9A UNIFORM LAwS ANN. 550 (1965) contains a list of the twenty-eight jurisdictions which have adopted this act. 
Rules of Evidence ${ }^{11}$ and the Uniform Interstate and International Procedure Act. ${ }^{12}$

The actual value of the state and uniform judicial notice statutes can only be determined by reference to the requirements which a pragmatically effective statute should fulfill. ${ }^{13}$ The first requisite

11 This set of rules contains provisions pertaining to judicial notice. Unmor RULes of Evidence 9-12. Rule 9 (2) (b) provides that the court may take judicial notice of foreign country law without request by a party; rule $9(3)$ requires that judicial notice must be taken "if a party requests it and (a) furnishes the judge sufficient information to enable him properly to comply with the request" and (b) gives notice to the adverse party.

Califoruia, Kansas, and New York have adopted statutes almost identical to the Uniform Rules of Evidence. CAL. Evidence CoDE $\S \S 450-60$ (effective Jan. 1, 1967); Kan. Gen. Stat. Ann. § 60-409 (1964); N.Y.R. Civ. Prac. 4511. The Panama Canal Zone has also adopted the Uniform Rules of Evidence, including those provisions relating to judicial notice of foreign country law. C.Z. CoDE tit. 5, \$§ 2761-64 (1963).

${ }_{12}$ Need for reform in the area of civil litigation having interstate and international aspects gave rise in 1958 to the establishment of a Commission and Advisory Committee on International Rules of Judicial Procedure. See Act of Sept. 2, 1958, 72 Stat. 1743. The Commission obtained the assistance of the Columbia Law School Project on International Procedure under the direction of Professor Hans Smit. An initial draft act was promulgated by this Commission and approved by the Conference of Commissioners on Uniform State Laws and the American Bar Association in the form of the Uniform Interstate and International Procedure Act in 1962. See 9B UNIForm Laws ANn. 80 (Supp. 1965). Arkansas, Oklahoma, and the Virgin Islands have subsequently adopted this act. ARk. STAT. ANN. § 27-2504 (Supp. 1965); Okla. Laws 1965, ch. 144, at 168; V.I. Code tit. 5, $\$ \S 4926-28$ (Supp. 1965). See generally Leflar, Act 101 -Uniform Interstate and International Procedure Act, 17 ARK. L. REv. 118 (1963); Miller, supra note 1, at 1069-72; Note, 11 AM. J. CoMp. L. 415 (1962).

${ }^{13}$ Judicial notice has been viewed as the solution to various problems. It is argued that the establishment of a judicial notice statute will tend to decrease "contradictory conclusions as to the interpretation of identical provisions of foreigu law." Emanuel v. Feiereman, 202 Cal. App. 2d 552, 561, 20 Cal. Rptr. 883, 890 (Dist. Ct. App. 1962) (dictum), speaking about the purposes of the California statute, CAL. Grv. Proc. Code $\S 1875$. The financial burden on the impecunious party seeking to prove foreign law has drawn criticism of the old rules by Professor Nussbaum, who views the device of judicial notice as a definite improveinent in this field. Nussbaum, Proof of Foreign Law in New York: A Proposed Amendment, 57 Corum. L. REv. 348 (1957); Nussbaum, Proving the Law of Foreign Countries, 3 AM. J. Comp. L. 60, 66 (1954). Professor McCormick views rigid requirements regarding expert witnesses as unnecessary hindrances. McCormick, Judicial Notice, 5 VAND. L. REv. 296 (1952). "[T]he adoption by the federal courts and by the states which have not yet adopted it, of the flexible procedure of judicial notice, whereby the court is free to get its information from any convenient source, seems the path of justice and common sense. The courts could then accept, as they should, the opinions of experts submitted by letters instead of being limited to cross-examined testimony." Id. at 309 . As to the procedural improvements attributable to judicial notice see generally I CALIF. LAw Revision REP. I-21 (1957); Joseph, How the Adoption of the Uniform Rules of Evidence Would Affect the Law of Evidence in Oregon: Rules 1-16, 41 Ore. L. REv. 275 (1962).

It is, however, interesting to note that the use of judicial notice with regard to foreign country law has not been universally favored. It is argned by the opponents 
is a means by which the foreign law may be effectively utilized to govern all or part of a locally instituted action-this is the basic purpose of the judicial notice statutes. Secondly, in order to allow the adversary system to function fully, a means of notice to the adverse parties ${ }^{14}$ must be provided. Thirdly, an effective statute must require that the tenor of the foreign law be a question of law for the court and subsequently reviewable on appeal. ${ }^{15}$ Finally, certain

of judicial notice that the "roles" of the courts and litigants would be detrimentally altered by such a statute, as the court would be overburdened and the attorneys not responsible for researching the foreign law. See, e.g., Arams v. Arams, 182 Misc. 328, 182 Misc. 336, 45 N.Y.S.2d 251 (Sup. C. 1943); Sommerich \& Busch, The Expert Witness and the Proof of Foreign Law, 38 ConNell L.Q. 125, 156-59 (1953); Stern, supra note 7, at $40-45$. But see Currie, supra note 1, at 991: "Judicial notice cannot dispense with the necessity of work to find the rule of decision. It is unrealistic and probably unwise to expect judicial notice to change the relative roles of court and counsel by shifting the burden of that work to the court. It is positively dangerous to entertain the notion that judicial notice can dispense with procedures which safegnard the fairness of the adversary process."

In this connection it is interesting to note that the Massachusetts bar, upon passage of the earliest judicial notice statute, felt it incumbent upon itself to warn the members of the bar that "whenever the law of any jurisdiction outside of Massachusetts shall be material, it shall be the duty of counsel to call to the attention of the court such authorities or other material relating to the question as they wish the the court to consider." Mass. L.Q., Nov. 1931, p. 8.

${ }^{14}$ For a discussion of the need for notification of adverse parties under a judicial notice statute, see 1 Calif. LAw Revision REP. I-20 to -21 (1957).

${ }^{16} \mathrm{~A}$ closely related problem, assuming the existence of a statute which makes foreign law a reviewable question of law, is whether or not the appeals court may do its own research and even notice law which was never brought to the attention of the trial court. Allowing an appeals court to do its own research has been criticized. See Sommerich \& Busch, Forfign Law: A Guide to Pleading and Proof 68 (1959). It would seem that courts have generally not allowed the introduction of foreign law for the first time on appeal. See, e.g., People v. De Casaus, 194 Cal. App. 2d 666, 15 Cal. Rptr. 521 (Dist. Ct. App. 1961); Donahue v. Dal, Inc., 314 Mass. 460, 50 N.E.2d 207 (1943); Lennon v. Cohen, 264 Mass. 414, 163 N.E. 63 (1928). Some appellate courts have applied this general rule so rigidly as to achieve rather unrealistic results. See, e.g., Emanuel v. Feiereman, 202 Cal. App. 2d 555, 20 Cal. Rptr. 883 (Dist. Ct. App. 1962), where an appellate court reversed a lower court decision obviously based on foreign law because the lower court had failed to include in the record that it had taken judicial notice of certain provisions of Soviet law.

There are, however, also interesting exceptions to this rule. The Massachusetts court under its judicial notice statute, Mass. ANN. LAws ch. $233, \S 70$ (1956), said: "We deem it our duty to decide this actual controversy. Even if not required to take judicial notice of the law of Nevada, which is said not to have been brought to the attention of the court below, we are nevertheless authorized to do so by ... [the state statute]." De Gategno v. De Gategno, 336 Mass. 426, 431, 146 N.E.2d 497, 500 (1957). Likewise, in New England Trust Co. v. Wood, 326 Mass. 239, 93 N.E.2d 547 (1950), where the law of Turkey had not been fully brought to the attention of the court below, the court noted that "although not so required, we might take notice of Turkish law." Id. at 243, 93 N.E.2d at 549; accord, Walker v. Lloyd, 295 Mass. 507, 4 N.E.2d 306 (1936); cf. Tsacoyeanes v. Canadian Pac. Ry., 339 Mass. 726, 162 N.E.2d 23 (1959). The Massachusetts appellate courts have been able to achieve results contrary to the general rule by judicially transforming their statute, which is 
realistic considerations dictate that in the instance where the court receives inadequate information concerning the foreign law and cannot justly base its decision upon that law, it be empowered to dismiss the action. ${ }^{10}$

\section{Foreign Law as Basis of a Local Action}

As previously stated, one basic purpose of any judicial notice statute is the effective ascertainment of foreign law so as to allow such law to constitute the basis of an action in the local court.

couched in mandatory terms, see note 21 infra, into a permissive statute. The Ianguage of the Massachusetts decisions has created the impression that whether or not foreign law not previously introduced is noticed initially on appeal will be purely a matter of discretion. The Massachusetts courts have also applied this interpretation to their statute when faced with other situations. Cf. notes 21-22 infra and accompanying text.

It would seem that a procedure allowing the appellate court to judicially notice a foreign law which had never been brought to the attention of the parties would be extremely unfair to the party adversely affected by such foreign law. This situation could be cured by permitting the appellate court to notice foreign law independently, but requiring that court to give sufficient notice to the parties. The Uniform Rules of Evidence specifically aim at this problem. Rule 12 (3) states "the reviewing court in its discretion may take judicial notice of any matter specified in Rule 9 whether or not judicially noticed by the judge," UNIFORM RULEs of EviDENCE $12(3)$, while rule $12(4)$ provides that if the appeals court wishes to notice matter not noticed previously, it must provide the parties with sufficient time in which to present relevant information. UNIFORM RULES OF EvidENCE 12 (4).

${ }^{16}$ See note 83 infra. It should be noted that, due to choice of law considerations, the foreign law may not come into play at all as the rule of decision. See generally Currie, Selected Essays on the Conflict of Laws (1963); Garfinkel, Conflict of Laws $-A$ Survey of Past and Contemporary Theory, 16 Hastings L.J. 21 (1965). An inability to ascertain the content of foreign law may pose an interesting choice of law dilemma, however. If the forum's choice of law rule points to an unascertainable foreign law as the rule of decision, the forum may have no alternative to dismissal. Whether such dismissal is with or without prejudice may depend upon whether the forum will conclude that the party invoking the foreign law has failed to meet his burden of proof or whether the dismissal is viewed as deriving from application of the doctrine of forum non conveniens. Should the latter tack be taken, the judgment may be framed in such a manner that it would not be res judicata on the merits and the action could be brought in the foreign state or another state more able to ascertain the law, if jurisdiction can be obtained. However, the prior determination that foreign law is applicable might not be deemed binding in the eyes of a different jurisdiction in which the action is subsequently brought, although it may be argued that the first choice of law determination was res judicata. An alternative to dismissal and its potential horrors would be utilization of the various common law presumptions as to the content of unproven foreign law. See note 6 supra.

A choice of law rule which prohibits a local court from applying a foreign law which contravenes the public policy of the forum has on occasion caused courts to misapply the term "judicial notice." When faced with such an antipathetic law, one court has stated that it would not take "judicial notice" of it. See Fitzgerald v. Fitzgerald, 66 N.J. Super. 277, 168 A.2d 85I (N.J. Super. Ct. 1961) (dictum). The obvious error here is that the courts have noticed the foreign law in order to make the determination that it is contrary to local policy. 
The thoroughness with which the foreign law on a particular point can be ascertained is governed by innumerable variables such as the availability of expert opinion on the foreign law, familiarity with comparative law concepts on the part of the court and attorneys, and the adequacy of the local library facilities. ${ }^{17}$ The attempted use of judicial notice statutes, most of which entail certain inflexible distinctions, ${ }^{18}$ for the purpose of dealing with the extremely flexible situations which arise in this area has placed upon the courts the burden of extricating themselves from certain diffcult situations. Regardless of whether the statutes have been couched in mandatory or permissive terms, ${ }^{19}$ the courts have almost invariably reached the pragmatic result of noticing that law and only that law which could, under the particular circumstances, be effectively ascertained. ${ }^{20}$

It is instructive to view the various state judicial notice statutes and the ways in which the state courts have responded to individual concrete cases. The Massachusetts statute, for example, is extremely broad on its face and requires notice of any "material" statute or case law extant in any jurisdiction.21 The Massachusetts courts, however, have found it difficult to break away from the common law rules. While they have not specifically stated that pleading and proof are required, the fact that sufficient "evidence" is still a judiciallyimposed requisite would seem to indicate that some form of pleading and proof may be necessary and that the Massachusetts courts will not consider noticing law as to which they have not been given adequate information. ${ }^{22}$

${ }^{17}$ See generally Nussbaum, Proving the Law of Foreign Countries, 3 AMr. J. CoMp. L. 60 (1954); Nussbaum, The Problem of Proving Foreign Law, 50 YALE L.J. 1018 (1941); Sommerich \& Busch, The Expert Witness and the Proof of Foreign Law, 38 CORNELL L.Q. 125 (1953); Stern, supra note 7. One aspect of the adequacy of library facilities is the availability of translations of foreign materials. A discussion of some of the translations available is contained in Szladits, Note on Translations of Foreign Civil and Commercial Codes, 3 AM. J. CoMp. L. 67, 68-71 (1954).

${ }^{18}$ See text accompanying notes $42-47$ infra.

${ }^{19}$ Generally, statutes which require the local court to judicially notice foreign law are termed "mandatory" and those which make judicial notice of foreign law a matter of discretion with the court are termed "permissive."

${ }^{20}$ See notes 21-38 infra and accompanying text.

${ }^{21}$ Mass. ANN. LAws ch. 233, $\S 70$ (1956): "The courts shall take judicial notice of the law of the United States or of any state, territory or dependency thereof or of a foreign country whenever the same shall be material." (Emphasis added.)

${ }_{22}$ Professor Nussbaum has noted the strange phenomenon occurring in the Massachusetts court. "The Massachusetts courts seem not much impressed by the precept of their legislature ... . [Citation to Rodrigues v. Rodrigues, 286 Mass. 77, 190 N.E. 20 (1934)] where the court 'took judicial notice' on the basis of expert testimony! 
Four other states, North Carolina, ${ }^{23}$ Mississippi, ${ }^{24}$ California, ${ }^{25}$ and Virginia ${ }^{26}$ also have statutes which, on their faces, may be termed

Perhaps the Massachusetts courts interpret the precept merely as barring notice of foreign law from the jury." Nussbaum, Proving the Law of Foreign Countries, 3 AM. J. Comp. L. 60 n.3 (1954). In Rodrigues v. Rodrigues, supra, the court noted that "merely to direct attention to the law of a foreign country written in a foreign tongue does not make it a matter for judicial knowledge." Id. at 83, 190 N.E. at 22. It has not been unusual for the Massachusetts courts to depart from the strict requirement of the Massachusetts statute. See, e.g., Bergeron v. Bergeron, 287 Mass. 524, 192 N.E. 86 (1934); Gorrasi v. Manzella, 287 Mass. 165, 191 N.E. 676 (1934); Lennon v. Cohen, 264 Mass. 414, 163 N.E. 63 (1928); Mass. L.Q., Oct.-Dec. 1939, p. 8. $B u t$ cf. Tsacoyeanes v. Canadian Pac. Ry., 339 Mass. 726, 162 N.E.2d 23 (1959) (where foreign law not fully brought to attention of court, it might take judicial notice of of such law); New England Trust Co. v. Wood, 326 Mass. 239, 93 N.E.2d 547 (1950). Cf. note 15 supra.

${ }^{23}$ N.C. GEN. STAT. $\$ 8-4$ (1953): "When any question shall arise as to the law of . . . any foreign country, the court shall take notice of such law in the same manner as if the question arose under the law of this State."

${ }_{24}$ Miss. CODE ANN. $\$ 1761$ (1956): "When any question shall arise as to the law of the United States, or of any other state or territory of the United States . . or any foreign country, the court shall take notice of such law in the same manner as if the question arose under the law of this state." (Emphasis added.)

${ }^{25}$ CAl. Crv. Proc. Code $\$ 1875$ (Supp. 1965). The exact wording of the statute makes it a bit difficult to determine whether or not the drafters intended the statute to be mandatory. The statute states merely: "Courts . . . take judicial notice of" as opposed to the other mandatory statutes which say "the Court shall take notice." (Emphasis added.)

See Note, 32 GAdIF. ST. BAR J. 564 (1957), which indicates that the California statute is also mandatory with respect to foreign country law. In support of this contention the author cites several California decisions where the statute was held to be mandatory with regard to the law of sister-states. Id. at 566. Since the California statute makes no distinction between the laws of sister-states and foreign countries, as do N.Y.R. Grv. Prac. 4511, and Uniform Rule of Evidence 9, the analogy to foreign country law from these decisions involving sister-state law may be apt.

However, it should be noted that the California statute effective January 1,1967 , is an enactment quite similar to the Uniform Rules of Evidence. CAL. Evidence CodE $\S \S 310 \cdot 11,450-60$.

Section 310 reiterates the rule that the foreign law is a question of law for the court; $\$ 311$ provides for application of local law or dismissal if the foreign law cannot be determined; $\S \S 452-53$ provide that the foreign country law may be noticed by the court, and must be noticed if requested and sufficient information is supplied.

Despite the much clearer enumeration in the new California statute, the comment to $\S 452(f)$, states "subdivision $(f)$ should be read in connection with $\$ \$ 310,311$, 453, and 454. These provisions retain the substance of the existing law which was enacted in 1967 upon recommendation of the California Law Revision Commission." Comment-Assembly Committee on Judiciary in CAL. Evidence CoDE $\$ 452$ (f), at 57 .

26 "Whenever in any case it becomes necessary to ascertain what the law, statutory or otherwise, of another ... country ... is, or was at any time, the court ... shall take judicial notice thereof, and may consult any book of recognized authority purporting to contain, state or explain the same, and may consider any testimony, information or argument that is offered on the subject." VA. CoDE ANN. § 8-273 (1957).

The West Virginia statute, W. VA. CODE ANN. $\$ 5711$ (1961), is identical to the Virginia statute and includes the same reference to the judicial notice of foreign law. However, the title of the section and the comment following it both indicate that it only applies to United States and sister-state law. 
mandatory and which apply to sister-state and foreign country law alike. Although no cases involving foreign country law have been found in which these statutes have been construed, several state decisions do present a rather interesting result. Under their respective judicial notice statutes, the courts of North Carolina and Mississippi have judicially noticed sister-state laws where no pleading or proof whatsoever has taken place and where the courts have not been presented with any information regarding the foreign law. ${ }^{27}$ It would seem significant to observe in this connection that sisterstate law would not, under most circumstances, be subject to those variables ${ }^{28}$ which might make foreign country law difficult to determine. ${ }^{29}$

The conclusion that the courts will only notice that law which they can ascertain is reinforced by the history of the New York statutes. Prior to 1963, New York had a permissive statute which had been interpreted as requiring pleading and proof of foreign law..$^{30}$ The new New York statute ${ }^{31}$ was believed to be of a more mandatory

New Jersey also has a mandatory provision, although it is questionable whether it applies to foreign country law. The New Jersey amendment, N.J. STAT. ANN. § 2A:82-27 (Supp. 1965), increased the purview of the earlier judicial notice statute to include the law of a foreign country; however, the old New Jersey statute, N.J. STAT. ANN. § 2A:82-31 (1952), which asserts that $\S 2 A: 82-27$ does not include the law of foreign countries, is not listed as having been repealed in the 1965 supplement.

${ }^{27}$ In Arnold v. Ray Charles Enterprises, 264 N.C. 92, 141 S.E.2d 14 (1965), the court took judicial notice of New York law although neither party made any reference to it. Accord, Floyd v. Vicksburg Cooperage Co., 156 Miss. 567, 126 So. 395 (1930); Caldwell v. Abernethy, 231 N.C. 692, 58 S.E.2d 763 (1950).

${ }^{28}$ See note 17 supra and accompanying text.

20 The court will always - even given a statute which applies mandatorily to both sister-state and foreign country law alike-judicially notice only those laws it can pragmatically ascertain. See text accompanying notes 20-28 supra and text accompany. ing notes 31-38 infra. It is submitted that since it will usually be more pragmatically possible to ascertain sister-state law, the courts will draw a distinction between sister-state and foreign country law and will almost always follow the literal wording of the judicial notice statutes when confronted with sister-state law, while requiring some degree of proof when dealing with foreign country law.

${ }^{30}$ N.Y. Sess. Laws 1943 , ch. 536, § 6. See Walton v. Arabian American Oil Co., 233 F.2d 541 (2d Cir.), cert. denied, 352 U.S. 872 (1956); Arams v. Arams, 182 Misc. 328, 182 Misc. 336, 45 N.Y.S.2d 251 (Sup. Ct. 1943).

31 "Every court may take judicial notice without request of ... the laws of foreign countries or their political subdivisions. Judicial notice shall be taken of matters specified in this subdivision if a party requests it, furnishes the court sufficient information to enable it to comply with the request, and has given each adverse party notice of his intention to request it. Notice shall be given in the pleading or prior to the presentation of any evidence at the trial, but a court may require or permit other notice." N.Y.R. Crv. PrAc. 4511 (b). Subsection (c) provides that the determination of the foreign law shall be a matter for the court, reviewable on appeal. N.Y.R. Crv. Prac. 4511 (c). Subsection (d) allows the court to "consider any testimony, document, information or argument on the subject, whether offered by a party or discovered through its own research." N.Y.R. Grv. Prac. 4511 (d). 
nature..$^{32}$ However, a recent decision would seem to indicate that the courts have not altered their position; ${ }^{33}$ they will not judicially notice laws as to which they have not been adequately informed..$^{34}$ The conclusion that the New York statutes have not done away with the pleading and proving of foreign country law is buttressed by the fact that foreign law is required to be pleaded "where a cause of action or defense is based upon the law of a foreign country ...."35

The Maryland statute requires its courts to "take judicial notice of the common law and statutes of every state, territory and other jurisdiction of the United States, and of every other jurisdiction having a system of law based on the common law of England."36 Such a statute seems to reflect recognition of the variables which enter into each individual determination of foreign law. Here, the Maryland legislature has determined that the problems involved in ascertaining the tenor of laws of countries whose legal systems are totally different from the laws of that state are too great to require that such laws be judicially noticed. It is, however, rather interesting to note to what convoluted extremes the Maryland courts have gone. In Reisig v. Associated Jewish Charities ${ }^{37}$ the court was confronted with a claim based on the "law of Societies" which had been promulgated by Palestine under Ottoman rule and which had been retained under the British mandate and administered according to the common law of England. "In this situation,

\footnotetext{
${ }^{39}$ Sommerich \& Busch, Judicial Notice of Law Under New York Civil Practice Law and Rules, N.Y.L.J., Dec. 17-18, 1962, p. 4.

ss Petition of Petrol Shipping Corp., 37 F.R.D. 437, 440 (S.D.N.Y. 1965). The court felt that lack of sufficient information regarding the foreign law, and nnfamiliarity with the foreign legal system in question (law of Greece), gave the court discretionary power to refuse to judicially notice the foreign country law.

34 Thus, it would seem that the new New York statute, N.Y.R. Crv. Prac. 4511 , is still permissive with regard to foreign country law and the realistic result is that a New York court will not judicially notice any foreign country law unless enough "evidence" is presented to it so as to enable it to determine the substance of the foreign law.

The illusory differences between the old statute, N.Y. Sess. Laws 1943, ch. 536, $\S 1$, and the new N.Y.R. Grv. Prac. 4511, are well stated by one commentator: "How effective this innovation [rule 4511] will be in practice is difficult to say. A court reluctant to take judicial notice of foreign law will always be able to state that it has not been supplied with sufficient information." Herzog, Conflict of Laws, 14 SYRACUSE L. REV. 147, 154 (1962).

${ }^{25}$ N.Y.R. Crv. Prac. 3016 (e). (Emphasis added.) The enactment of this section supports the conclusion that the New York legislature did not intend to do away with the requirement of pleading the foreign law. Sommerich \& Busch, Judicial Notice of Law Under New York Givil Practice Law and Rules, N.Y.L.J., Dec. 17-18, 1962, p. 4.

${ }^{30} \mathrm{MD}$. ANN. CODE art. 35, $\S 47$ (1965). (Emphasis added.)

sт 182 Md. 432, 34 A.2d 842 (1943).
} 
the courts of Maryland are specially required to take judicial notice of this foreign law and to apply it to the facts of the particular case, 'as would be proper if such foreign law were domestic law.' "38

The Connecticut ${ }^{39}$ and Michigan $^{40}$ statutes would seem to impose a more permissive judicial notice mandate. They provide that the printed statutes and judicial decisions of foreign countries shall be prima facie evidence and that the courts may take judicial notice of them. Such permissive statutes are quite realistic in terms of the problems mentioned above since they do not require the local court to judicially notice any foreign country laws. Thus, when faced with law about which no information can be ascertained, these courts will not be forced to contort the notice statute. ${ }^{41}$

Realizing the difficulty in ascertaining a specific foreign law, the uniform laws have attempted to fix rigid classifications for the use of the judicial notice device. The Uniform Judicial Notice of Foreign Law Act ${ }^{42}$ is mandatory with regard to sister-state law, ${ }^{43}$ but still retains the pleading and proof requirements with regard to the law of foreign countries.4 Rule 9 of the Uniform Rules of Evidence is somewhat of a hybrid. Sister-state law must be noticed by a court and the court may on its own motion judicially notice the law of a foreign country. ${ }^{45}$ The court must, however, judicially notice foreign country law if three conditions are met: first, the parties must request judicial notice of the foreign law; second, notice must be given to the adverse party; finally, the court must be supplied with "sufficient information to enable ... [it] properly to comply with the request." ${ }^{46}$ It would seem that this last provision preserves a large measure of judicial discretion which in effect makes the statute permissive. ${ }^{47}$ The Uniform Judicial Notice of

\footnotetext{
${ }^{38}$ Id. at 437,34 A.2d at 844.

${ }^{30}$ CONN. GEN. STAT. ANN. $\$ \S 52-163$ to -164 (1960). It should be noted that one of the Connecticut statutes, CoNN. GEN. STAT. AN. $\$ 52-163$ (1960), speaks in mandatory terms with respect to foreign statutes, while the other, ConN. GEN. STAT. ANN. \$ 52-164 (1960), is couched in permissive terms regarding foreign judicial decisions. However, there is dicta in Bohenek v. Niedzwiecki, 142 Conn. 278, 281, 113 A.2d 509,510 (1955), construing both statutes as permissive.

SO Mich. Stat. ANN. \$§ 27A.2114-.2115, 27A.2118 (1962).

"See notes 21-22 supra and accompanying text.

¿See note 10 supra.

¿3 Uniform Judicial Notice of Foreign Law Act $\$ 1$.

" Uniform Judicial Notice of Foreign Law Act $\$ 5$.

¿See note 11 supra.

s6 UNiform RULE of Evidence 9 (3).

${ }^{4}$ Cf. notes 32-34 supra and accompanying text.
} 
Foreign Law Act and the Uniform Rules of Evidence reflect a realistic approach to actual courtroom needs and situations since they seem to recognize that sister-state law will normally be more easily ascertained. However, the development of hard and fast classifications in this area seems of dubious value and such rubrics were avoided in the new Uniform Interstate and International Procedure Act, which represents the most flexible approach to date. The draftsmen did not use the words "judicial notice" and eliminated all mandatory or permissive language. The act speaks only of "determining" the foreign law and presents the basic, pragmatic rules necessary for an accurate determination of such law. ${ }^{48}$ Since it has only recently been adopted in three jurisdictions, Arkansas, ${ }^{49}$ Oklahoma and the Virgin Islands, ${ }^{50}$ no decisions construing the act are available.

\section{Notice Requirement}

Under the common law, notice to the adverse party was embodied in the pleadings. In the more traditional judicial notice acts exemplified by the earlier state statutes, no mention is made of any notice requirement. ${ }^{51}$ For example, the Mississippi ${ }^{52}$ and North Carolina ${ }^{53}$ enactments provide that the court shall take notice of the foreign law in the same manner as if the question arose under the law of the forum state. On its face, such statutes would seem to eliminate any notice requirement, although some sort of notice might be achieved through various court-rationalized requirements for pleading. ${ }^{54}$ However, notice is of such significance that it should be specifically

\footnotetext{
4 Uniform Interstate and International Procedure Act art. IV. Section 4.01 of article IV provides for notice to the adverse party, $\S 4.02$ empowers the court to consider any source of law, and $\S 4.03$ provides that the foreign law shall be a question of law determined by the court and reviewable on appeal.

${ }^{\circ}$ Ark. Stat. AnN. § 27-2504 (Supp. 1965).

so Okla. Laws 1965, ch. 144, at 168; V.I. Cone tit. 5, $\$ \S 4926-28$ (Supp. 1965).

$\because$ E.g., MASS. ANN. LAws ch. 233, § 70 (1956); Miss. CODE ANN. \$ 1761 (1956); N.C. GEN. STAT. § 8-4 (1953); VA. CODE ANN. § 8-273 (1957).

22 Miss. CODE ANN. $\$ 1761$ (1956).

${ }^{5}$ N.C. GeN. STAT. \$ 8-4 (1953).

54 In the past, the courts of these states have strictly adhered to the letter of their judicial statutes and, at least with regard to the law of sister states, have required no pleading or notice whatsoever. See note 27 supra and accompanying text. It might be argued that since neither of these states has ever had occasion to determine foreign country law and their courts have not specifically dispensed with some form of pleading and proof in such a situation, some form of notice might come into play through court-made requirements of "sufficient evidence" or pleading and proof similar to those developed by the Massachusetts courts. See note 22 supra and accompanying text.
} 
provided for by statute, and litigants should not have to rely on a court's broad interpretation of a general judicial notice statute. Thus, several state statutes contain the express requirement that "reasonable notice" be given. ${ }^{55}$

Two of the three uniform acts also have sections specifically applicable to the notice problem. ${ }^{56}$ Rule 9 of the Uniform Rules of Evidence does not provide for notice to the parties when the court takes, as it is required to do, judicial notice of sister-state law. ${ }^{67}$ As to foreign country law, however, judicial notice may not be taken until three conditions have been met, ${ }^{58}$ one of which is notice to the adverse party. Rule 12 , moreover, provides that in a subsequent proceeding a judge taking judicial notice of "matter not theretofore so noticed in the action shall afford the parties reasonable opportunity to present information relevant to the propriety of taking such judicial notice ...."59 Section 4.01 of the Uniform Interstate and International Procedure Act requires a party "who intends to raise an issue concerning the law of any jurisdiction ... outside this state ... [to] give notice in his pleadings or other reasonable notice." ${ }^{\text {Bo }}$ Section 4.02, however, allows the court to

65 E.g., Gal. Crv. Proc. Code $\S 1875$ (4) (Supp. 1965), to be replaced by Cal. EvideNce Code $\S \S 310-11$, $450-60$ (effective Jan. 1, 1967); MD. ANN. Code art. 35, $\S 50$ (1957). The New York statute specifically provides that "notice shall be given in the pleadings or prior to the presentation of any evidence at the trial, but a court may require or permit other notice." N.Y.R. Crv. PrAc. 4511 (b). However, rule 4511 (b) also allows the trial court, at its discretion, to take judicial notice of tbe foreign country law even if not so requested. It is questionable whether any notice to the parties will be requisite in this latter situation. Another New York statute, N.Y.R. Crv. Prac. 3016(e), requires notice for the adverse party from a litigant relying on foreign law but does not refer specifically to the judicial notice situation. See McLaughlin, Supplementary Practice Commentary to Rule 4511(b), in N.Y.R. Civ. Prac. 4511 (b), at 41.42 (Supp. 1965).

It might be argued that its proviso that "a court may require or permit other notice" requires the court to give notice to the parties before the court takes judicial notice. It is to be noted that this sentence proviso is not included in UNIFORM RULE of Evmence 9, from which the New York law was drawn. Cf. Legislative Studies of Reports in N.Y.R. Civ. Prac. 4511 (b), at 369-70, indicating that notice is not required when judicial notice is taken.

so Since the Uniform Judicial Notice of Foreign Law Act $\S 5$ does not apply to foreigu country law, it is not directly applicable in this situation. In states which have adopted only this act, the common law requirement of pleading and proof of foreign country law applies and notice is effectuated through the pleadings. Western Assur. Co. v. Bevacqua, 209 N.E.2d 249 (Ohio C.P. 1964); accord, Witt v. Realist, Inc., 18 Wis.2d 282, 118 N.W.2d 85 (1962).

E7 UNIFORM RULE OF Evidence 9.

${ }^{85}$ See note 46 supra and accompanying text.

${ }^{\circ}$ UNIFORM RULE OF EvIDENCE 12 (4). See note 15 supra.

oo Uniform Interstate and International Procedure AcT $\$ 4.01$. 
consider material on its own, and there is no provision which insures that the parties will receive notice in such a situation. ${ }^{61}$

A problem that arises in conjunction with the notice requirement is whether a court, once its attention and that of the adverse party has been drawn to the law of another country, may judicially notice recent foreign statutes or cases which are unknown to the parties. ${ }^{62}$ Certainly the court should be able to do so. Once the party is put on notice that the law of a foreign state will be decisive or germane, it is his duty to research that law just as he would in a domestic case. Assuming that judicial notice is to be taken, ${ }^{63}$ there can be no argnment as to the remoteness of the law or decisions under it. The law of a foreign country is a composite of various sources; certainly that law cannot be judicially noticed unless the forum court is allowed to approach the substantive foreign law in the same thoroughgoing manner as it would the law of the forum.

A corollary to this is that once notice is provided, courts should not be restricted as to the particular sources to which they may look when taking judicial notice of foreign law. Various states have recognized this question and have made specific reference to foreign law sources which the courts might consider. New York allows the court to "consider any testimony, document, information or argument on the subject."64 The Virginia statute permits the court to "consult any book of recognized authority purporting to contain, state or explain ... [foreign law], and may consider any testimony, information or argument that is offered on the subject."65 The latter statute appears to place no limit whatsoever upon the sources available to the court. ${ }^{60}$ Other state statutes make no reference whatsoever to sources to be used by the court in its determination of the foreign law; they neither refer to specific sources nor give the court a

${ }^{61}$ With regard to this situation, the Commissioner's Note to $\$ 4.02$ states: "The fear that a court might surprise the litigants with a decision based on its own research seems more apparent than real. Should the court come upon material that diverges substantially from that presented by the parties, it should, at least in the normal case, inform them of the fruits of its research. However, an inflexible notice requirement seems undesirable." 9B UNIFORM LAws ANN. 100 (Supp. 1965).

${ }^{62} \mathrm{Cf}$. note 15 supra.

${ }^{63}$ See note 17 supra.

64 N.Y.R. Crv. Prac. 4511 (Supp. 1965). A similar approach is taken in CaL. Crv. Proc. CoDE $\S 1875$ (Supp. 1965), to be replaced by CAL. Evidence Code $\S 454$ (effective Jan. 1, 1967).

${ }^{65}$ VA. CODE ANN. § 8-273 (1957).

${ }^{\circ 0} \mathrm{Cf}$. In re Reid, 198 F. Supp. 689 (W.D. Va. 1961), in which the court asserted that "the statute law of Virginia in effect requires its courts to take judicial notice of all of the decisions of all of the courts everywhere." Id. at 695 (dictum). 
wide range in this field. ${ }^{67}$ This has not, however, inhibited the Massachusetts courts, for example, from reaching some rather interesting and salutary results. In Universal Adjustment Corp. $v$. Midland Bank Ltd., ${ }^{68}$ the court took judicial notice of a Russian court decision of $1883,{ }^{60}$ a Russian-United States treaty of $1909,{ }^{70}$ and the Russian Government's comment on that treaty. ${ }^{71}$ Other Massachusetts decisions indicate that the court has not viewed the absence of specific sources as a limitation on its capacity to ascertain the appropriate law. Massachusetts courts have gone so far as to use inaccessible government information ${ }^{72}$ and recent foreign decisions unknown to the litigant. ${ }^{73}$ The liberality of these decisions and the applicable provisions of recent uniform acts ${ }^{74}$ accord with the necessity for a broad source of law.

\section{Foreign Law as Question for the Court}

Due to the undesirable results obtained if foreign law is viewed as a "fact," 75 the tenor of foreign law should quite definitely be a question of law for the court rather than a question of fact to be decided by the jury. This reform has, fortunately, found wide acceptance, ${ }^{76}$ although certain jurisdictions still adhere to the common law treatment of foreign law questions. ${ }^{77}$

\footnotetext{
${ }^{87}$ See statutes cited notes 21, 23-24 supra.

c8 281 Mass. 303, 184 N.E. 152 (1933).

${ }^{\circ} I d$. at 327,184 N.E. at 164 .

${ }^{70} \mathrm{Id}$. at 323,184 N.E. at 162 .

${ }^{71} \mathrm{Id}$. at 327,184 N.E. at 164 . Such a result would seem quite desirable. Once it is determined that the foreign law is to provide the rule of decision, it is necessary to ascertain as fully as possible the tenets of the foreign law. Any sources which elucidate that law would appear to be relevant and thus within the scope of judicial notice. Cf. text accompanying notes 62-63 supra.

72 In Petition of Mazurowski, 331 Mass. 33, 116 N.E.2d 854 (1954), the probate judge received information from the State Department relevant to questions of foreign law concerning administrative procedure and regnlation which were in the possession of high-ranking government executives but which was not directly available to the litigants.

${ }^{73}$ In Pilgrim v. MacGibbon, 313 Mass. 290, 47 N.E.2d 299 (1943), the court's attention had been drawn generally to the law of Nova Scotia, and it judicially noticed a new decision of the highest court of Nova Scotia: See also Ex parte Spears, $88 \mathrm{Cal}$. 640, 643, 26 Pac. 608, 609 (1891), where the court considered an entire volume of foreign law despite the fact that only one section of it had been pleaded.

7Uniform Interstate and INTERnational Proceddre Act § 4.02; UNIForm JUDicial Notice of Foreign LAw § 2; UNIFORM RULE OF Evidence 10.

${ }^{75}$ See notes 5-7 supra and accompanying text.

${ }^{70}$ All three Uniform laws contain provisions making foreign country law a question for the court. UNIForm INTERstate and INTERnational Procedure ACT $\$ 4.03$; UNIFORM JUDICIAL NOTICE OF FOREIGN LAW ACT § 5; UNIFORM RULE OF IVIDENGE 10 (4).

${ }^{77}$ Sommerich and Busch state that common law as to judicial notice prevails in
} 


\section{CONGLUSION}

As noted previously, several provisions would seem to be requisite in an effective foreign law statute. Briefly, these include a means by which an action in the local court may be based on foreign law; notice to the adverse parties; making foreign law a question of law; making a foreign law determination reviewable on appeal; and providing a method for the local court to dispose of the case if the foreign law cannot be ascertained. From a review of the foregoing case law, it may be seen that the various judicial notice statutes have not provided any unique methods of facilitating the first of these requisites, and the courts have been forced to resort to the traditional requirements of pleading and proof. ${ }^{78}$ Statutes which attempt to codify strict rules for situations which are subject to

Alabama, Colorado, Idaho, Nevada, New Hampshire, New Mexico and Utah. Sommerich \& Busch, Foreign Law: A Guide to Pleading and Proof 149-51 (1959).

The Alabama statute states: "The existence and tenor or effect of the laws of any foreign country may be proved as facts by parol evidence ..." ALA. CoDE tit. 7, \& 425 (1960). It would seem that foreign country law will be a question of fact. Whether a question for the court or jury is not specifically stated. However, it has been held that the lower court's finding as to foreign law is reviewable on appeal. Smith v. Blevin, 221 Ala. 24, 127 So. I55 (1929). This might indicate that the foreign law is either a reviewable question of fact or a question of law.

The Idaho provisions indicate that foreign statutory and common law must be proven as facts by evidence of expert witnesses, or certified copies of the foreign law. IDAHO CODE ANN. $\$ \S 9-304,9-307$ to -308 (1948). There seems also to be no specific provision indicating whether it is a question of fact for the court or jury. In Newell v. Newell, 77 Idaho 355, 293 P.2d 663 (1956), involving sister-state law, the court held that foreign law must be pleaded and proved. However, it did not state whether this was a question for the jury or the court. It might be argued that in the absence of a specific provision making it a question for the court, general common law principals would prevail and the foreign law would be a question for the fact-finder, whether he be judge or jury.

The Utah rule is somewhat more explicit. UTAF R. Crv. P. 44 (f) (1953). It states that a printed copy of a foreign statute purporting to have been printed by the foreign country is "presumptive evidence of the statute .... The unwritten ... law ... of a foreign country, may be proved as a fact by oral evidence. The books of reports of cases adjudged in the courts thereof must also be admitted as presumptive evidence of the unwritten or common law thereof." UTAH R. Civ. P. 44(f) (1953). The rule also provides that the court will determine the foreign law and this finding will be subject to appellate review. The trial and appellate courts are not limited in the sources to which they may look in order to ascertain the tenor of the foreign law. UTAK R. Crv. P. 44(f) (1953). It should be noted that such a statute seems to speak in mixed terms. That is, the langnage of the statute indicates foreign law will be proved as a fact at the lower level; yet it will be reviewable on appeal. It thus becomes difficult to discern whether the foreign law is being treated as "fact" or "law."

${ }^{78}$ See notes 21-50 supra and accompanying text.

One commentator has quite correctly stated that "the asserted advantages of judicial notice over the traditional methods of proof are Jargely illusory." Stern, Foreign Law in the Courts: Judicial Notice and Proof, 45 CAurf. L. REv. 23, 48 (1957). 
significant, unpredictable variables ${ }^{79}$ have been made flexible by the courts, ${ }^{80}$ thus arriving at a result identical with the situation prior to the enactment of the statutes. Because of the necessity of allowing for these variables, only a pragmatic approach can be effective in the area of judicial notice of foreign country law. ${ }^{81}$ Certainly the basic requirement of notice to the adverse party is fulfilled by traditional methods of pleading and proof and there is no need for a specific judicial notice statute to achieve this result. The traditional requirements of proof, enforced by flexible and non-technical rules of evidence which facilitate the employment of expert witnesses, would clearly result in use for decisional purposes of effectively ascertainable foreign law. This is simply a realistic approach-what cannot be "proven" under the liberal rules of evidence suggested cannot be realistically ascertained.

However, certain specific limitations should be engrafted upon the traditional methods of proof. The tenor of the foreign law should definitely be a question of law for the court, and it should thus be reviewable on appeal..$^{82}$ Further, in order to effectuate a pragmatic approach to proving foreign law, it is necessary that a court be allowed to use whatever sources of the foreign law it has at its disposal in addition to the usual methods of proof.

Finally, if the court does not receive adequate information concerning the foreign law and cannot therefore base its decision on that law, some method of disposing of the case should be formulated by the legislature. Absent statutory guidelines, several tacks appear to be open to a court faced with this problem. A court of the foreign jurisdiction whose law is apposite might be requested by letter to supply the law or to render an advisory opinion on the question. The law of the forum might be applied by employing the venerable but often problematic common law presumption that the forum and foreign laws are the same. A third alternative may be dismissal of the action, either on forum non conveniens grounds or on the ground that the party asserting the foreign law has failed to fulfill his burden of proof. ${ }^{83}$ Specific legislative directives in this

\footnotetext{
70 See note 17 supra and accompanying text.

${ }^{80}$ See notes $15,22,68-73$ supra and accompanying text.

${ }^{81}$ The Uniform Interstate and International Procedure Act comes very close to achieving this end. See notes 48-50 supra and accompanying text.

${ }^{82}$ See notes $15,75-77$ supra and accompanying text.

${ }^{83}$ See note 16 supra.

The only provision which would seem to be lacking in the Uniform Interstate and
} 
area would be preferable, however, in order to provide a certain and efficacious disposition in such situations.

II

\section{Deposition Practice}

Another major area in which there has been considerable interest is state procedures for obtaining testimonial evidence abroad. ${ }^{84}$ Almost all states have some type of statute or rule of court which provides for the taking of depositions in foreign jurisdictions. ${ }^{85}$ Two basic deposition procedures have developed..$^{86}$ One is the rather

International Procedure Act is one allowing the court to dispose of the case by dismissal or by application of the law of the forum in situations where it is impossible to determine the foreign law. CAL. Crv. Proc. CoDE $\$ 1875$ (Supp. 1965), to be replaced by Cal. Evidence Code $\$ 311$ (effective Jan. 1, 1967), contains such a provision. UNIFORM RULE OF EVIDENCE 10(3) also contemplates the situation where the court cannot determine the foreign law.

It might be argued that the adoption of certain choice-of-law methodologies would cover this situation. Under Professor Currie's governmental interest theory, for example, unascertainable law could never form the basis for a decision since it would be supplied in a choice-of-law situation only if the law [ex hypothesi unascertainable], by its terms and policies, evinces a legitimate governmental interest on the part of the foreign jurisdiction. See CURRIE, SELECTED ESSAYS ON THE CONFLICT OF LAws $35-40$ (1963).

84 See generally Dyer \& Samth, Federal Examinations Before Trial and Depositions Practice (1939); EbB, International Business 313 (1964); 8 Wigmore, Evidence $\S \S 2195 \mathrm{a}-\mathrm{e}$ (McNaughton rev. 1961); H. Jones, International Judicial Assistance: Procedural Chaos and a Program for Reform, 62 YALE L.J. 515 (1953); Miller, International Cooperation in Litigation Between the United States and Switzerland: Unilateral Procedural Accommodation in a Test Tube, 49 MrN. L. Rev. 1069 (1964); Note, 96 U. PA. L. REv. 241 (1947).

${ }^{8 \sigma}$ E.g., Cal. Civ. Proc. Cone $\S \S 2018$ (b), 2019, 2024 (Supp. 1965); Colo. Rev. Stat. Ann. R. Grv. P. 28 (1963); CH. GT. R. 28 (b); D.C. Code ANN. § 14-201 (1961); Ill. Rev. Stat. ch. 110, $\$ 101.19-2$ (1965); LA. REv. STAT. $\$ \S 3771,3773,3776$ (1950); Mass. Ann. Laws ch. 222, $\S 4$, ch. 233, $\$ \$ 41,43,52,56$ (1956); Mich. Stat. ANN. Gen. GT. R. 304.2 (1964); Míss. Code ANN. $\$ \S 1703-04,3980$ (1957); N.Y. Crv. Prac. LAw \$§ 3108, 3113 (a) (3), 3114; N.C. GEN. STAT. \$ 8-71 (Supp. 1965); N.C. Gen. Stat. § 8-83 (2) (1953); OHio Rev. Code AnN. \$ 2319.12, .14 (Page 1954); Okla. Laws 1965, ch. 144, at 168; TENN. CoDE ANN. $\$ \S 24-902$ (2), 24-916, 64-2306 (1955); UTAH R. Civ. P. 28 (b); VA. Code ANN. $\$ 8-305$ (Supp. 1964); W. VA. Code ANN. \$\$ 5734-35 (1961); WIS. STAT. $\S \S 326.09$ (2), 326.28 (1963).

For a complete listing of the various state statutes relevant to depositions taken out-of-state, see 8 Wigmore, Evidence $\S 2195 \mathrm{~b}$, at 99 n.28 (McNaughton rev. 1961). See also FED. R. Crv. P. 28 (b); Kaplan, Amendments of the Federal Rules of Civil Procedure, 1961-1963 (II), 77 HARv. L. Rev. 801, 811-14 (1964).

${ }^{80}$ Some writers have enumerated different classifications for the various means of obtaining depositions abroad. Generally these classifications have included letters rogatory, deposition by commission, deposition by "notice" to the adverse party and the deposition by stipulation. See DYER \& SMITH, op. cit. supra note $84, \S \S 585-607$; H. Jones, supra note 84 , at 519 .

These procedures have been sometimes intermingled, and clear dividing lines may not always be discernible. For example in DYER \& SMITH, op. cit. supra note 84, $\S \S 585-96$, depositions by stipulation are discussed under the heading Depositions 
familiar method of sending a letter rogatory to the foreign court. This is a device by which the local court requests the coercive assistance of the foreign court having jurisdiction over the desired deponent. ${ }^{87}$ The second method is a deposition by a locally appointed commission. Under this procedure, the local court designates an individual or other tribunal as the "commissioner" before whom the deposition is to be taken. ${ }^{88}$

The haphazard development of state deposition statutes is perhaps due to the recent development of extensive uniform laws dealing with this area. ${ }^{89} \mathrm{~A}$ review of the problems with which state enactments have attempted to deal may, however, reveal certain requirements which should be incorporated into statutes providing for the taking of depositions in a foreign jurisdiction.

\section{A. Commissions}

\section{Compliance with Foreign Court Requirements}

Since the ultimate success of a deposition abroad depends to a large degree on whether or not the foreign court will allow a locally

Abroad on Notice, and under the subheading of Depositions by Stipulation, id. § 589, a case involving commissions is discussed.

It is, however, questionable whether all four of these methods are of equal value with regard to depositions taken in foreign countries. Although they are generally authorized methods, depositions on notice and by stipulation would not seem to be as significant when the deposition is sought within a foreign jurisdiction. It is possible that this is due to a feeling on the part of attorneys that a deposition in a foreign country is a more formal matter than envisaged by these two procedures, and they thus seek a local court-initiated procedure such as letters rogatory or a commission for their dealings in a foreign country. It may, in part, also be due to the hostile view which civil law countries take of any foreign persons or officials taking depositions within their borders. See note 89 infra. In any case, it seems that the great bulk of relevant cases in this area has been concerned with depositions taken by means of commissions or letters rogatory. It is for this reason that the comment speaks, in the main, of letters rogatory and commissions.

Of course, if the foreign country allows foreign individuals to enter for purposes of a deposition and there is a voluntary deponent, stipulation or notice may prove quite satisfactory. $C f$. note 109 infra.

${ }^{87}$ See generally DyER \& SMITH, op. cit. supra note 84, $\$ \$ 602.07$; SYMPOSIUM, LeTTERS ROGatory (Grossman ed. 1956); \& WIGMORE, Evidence § 2195a (McNaughton rev. 196I).

${ }^{88}$ For statutory examples of the second deposition procedure see, e.g., CaL. Crv. Proc. Code § 2018 (b) (Supp. 1965); Colo. R. Civ. P. 28. See generally DYer \& SMITH, op. cit. supra note $84, \S \S 597-601$.

${ }^{80}$ The Uniform Foreign Depositions Act does not concern itself with the taking of depositions abroad for use in the local court. It directs its attention only toward the foreign court or litigant seeking a deposition in the local jurisdiction. See notes 113-14 infra. However, the Uniform Interstate and International Procedure Act $\S 3.01$, does deal with the situation under consideration. 
appointed commissioner to take a deposition within its borders, ${ }^{90}$ it is of utmost importance that the local statute contain provisions which will require the litigant to alert himself to certain foreign procedures. ${ }^{91}$ Concomitantly, the local statute must also facilitate compliance with such procedures.

Recognizing this need for compliance with foreign requirements, a few state statutes specifically admonish the local litigant to look to the relevant foreign law. For example, under the Colorado statute both parties will be forced to examine the foreign law prior to the deposition-the party seeking the deposition because he is required to do so by the statute, and the adverse party in order to reserve any objections to the procedure employed. ${ }^{22}$ Louisiana

${ }^{\circ 0}$ Certain countries, such as Switzerland, will not allow a foreign official to conduct a deposition proceeding within their borders. See 8 WIgMORE, Evidence $\$ 2195 \mathrm{a}$, at 91 n.I (McNaughton rev. 1961). "This attitude is based on the view that because a witness ordinarily is interrogated by a governmental official in Switzerland, it is an act of 'authority' under article 271 of the Penal Code and cannot be undertaken by a private person or an official of another country whenever the litigation is pending before a court outside Switzeriand." Miller, supra note 84 , at 1087 .

${ }^{\circ 1}$ It may be efficacious to enact a provision in the local statute which would require the local litigant and attorney to become cognizant of various foreign requirements before a commission will be appointed. H. Jones, supra note 84, at 519 . Ignorance of the fact that foreign country procedures may have to be met in this area could well have dire consequences for the attorneys and commissioners while in the foreign country. See id. at 520-21. Various of these practical problems confronting the local attorney are discussed in Doyle, Taking Evidence by Deposition and Letters Rogatory and Obtaining Documents in Foreign Territory, 1959 A.B.A. Skc. INT'L \& COMP. L.-PROCEEDINGS 37. A collection of the various deposition procedures required in the major countries of the world is contained in DYER \& SMIrH, op. cit. supra note $84, \S \S 1010-1355$. An interesting question arises where the deposition has been successfully taken and returned. If such deposition was taken under a procedure violative of the foreign law, but not the local law, may the party against whom the deposition is being introduced object to its introduction as evidence? It might be argued that to admit such a deposition would undermine the comity between the nations involved since it would give local validity to the violation of a foreign law by the local individual. Further, where the privileges of the foreign deponent are involved, there may be much stronger policy reasons for enforcing the law of the place where the deposition is taken. Apphication of a choice of law rule such as governmental interest analysis might well result in effect being given to the policy considerations of the place where the deposition is to be taken. See, e.g., Palmer v. Fisher, 228 F.2d 603 (7th Cix. 1955), cert. denied, 351 U.S. 965 (1956); Ex parte Sparrow, 14 F.R.D. 351 (N.D. Ala. 1953).

For a discussion of the various problems involved in a situation where the foreign country's procedures with regard to privileges differs from those of the court where the deposition is to be used, see Miller, supra note 84, at 1092-93.

os The Colorado statute, Colo. R. Crv. P. 28 (d), states: "Upon proof that notice to take a deposition outside the state of Colorado has been given, . . . the clerk shall issue a commission .... in the form prescribed by the state in which the deposition is to be taken, such form to be presented by the party seeking the deposition. Any error in the form or in the Commission . . . is waived unless objection thereto is filed before time fixed in the notice." It would seem that the practical result of 
specifically requires that the compulsory process for all depositions taken abroad "be governed by the laws of the state ${ }^{03}$ where the testimony is to be taken." 04 It is interesting to note that such a statute not only admonishes the litigant to ascertain foreign procedural rules, but it requires, as a matter of local Louisiana law, that the foreign procedure be adhered to. ${ }^{95}$

Various countries will differ as to which individuals they will allow to take depositions within their borders. State statutes have, with varying degrees of flexibility, addressed themselves to this

such a statute would be a deposition request which would be consistent with the foreign procedure.

It seems questionable whether the phrase "state in which the deposition is to be taken," may be construed to include "foreign country." Rule 28 (b) (2) indicates that a deposition in a foreign country may be taken "before such person or officer as may be appointed by commission or under letters rogatory." Colo. R. CIv. P. 28 (b) (2). It may be argued that rule 28 (b) (2) is merely modified by rule 28 (d) and that thus the "commission" contemplated in rule $28(\mathrm{~b})(2)$ must be "in the form prescribed by the state in which the deposition is to be taken." Colo. R. Crv. P. 28 (d).

It is, however, also possible that the legislature felt that too great a burden would be placed upon the parties if they were forced to ascertain the foreign country procedure, and rule 28 (d) may therefore be intended to apply only to depositions to be taken with the United States.

${ }^{83}$ It is not clear whether the local litigant is, under the language of the statute, required to follow the procedures of a foreign country. Cf. note 92 supra.

9\& LA. REV. STAT. $\$ 3773(1950)$. The result of this provision is to require litigants in the local courts to ascertain and follow the procedural laws of another jurisdiction. An interesting situation would arise if, for some reason, a litigant in a Louisiana court were to obtain a deposition in a foreign country by following procedures which were in violation of the foreign laws but which met the deposition requirements of Louisiana. If the Louisiana court were to follow the letter of its statute, it would seem that such a deposition should be excluded and any objection to its admission sustained. Cf. note 91 supra.

${ }^{95}$ In conjunction with a statutory provision requiring litigants to uncover the deposition requirements of foreign law, it could be extremely valuable if the local courts were coguizant of these requirements and could thus deny a request which failed to comply with the foreign law. The New York courts have been exceptionally attentive to divergences in foreign procedures. In United States Neckware Corp. v. Sinaco Co., 176 Misc. 51, 26 N.Y.S.2d 546 (Sup. Ct. 1941), the court, recognizing that the Swiss courts would not allow the usual commission within its borders, denied a motion for a commission to issue to the United States consular agent in Switzerland. Letters rogatory were designated as the correct procedure under the circumstances. Id. at 52, 26 N.Y.S.2d at 546. In In re Robbins' Will, 105 N.Y.S.2d 290 (Surr. Ct. 1950), a New York court refused to issue a commission to take the deposition of a physician in France. One ground for this refusal mentioned by the court was the fact that under French law, a doctor could not be compelled to testify concerning his patients. The court also noted the fact that French law did not provide a procedure by which witnesses could be compelled to give testimony for use in a case pending outside of France. Id. at 292.

It is submitted that such awareness of foreign procedure on the part of the local court may quite often save the litigants much time, expense, and embarrassment. It will certainly help direct the litigant toward the procedure which is acceptable in the foreign jurisdiction. 
problem.98 Some of these statutes, at least on their faces, appear to be limited in scope. They authorize depositions to be taken in a foreign country by a "commissioner" in that country, ${ }^{97}$ before a mayor or official of the foreign city ${ }^{98}$ or before a "notary" of the foreign country.99 Although all of these statutes do represent an attempt at flexibility, they nevertheless erect certain limitations which may be unnecessary. To facilitate the deposition process, it would appear desirable to defer completely to the foreign country and allow a deposition to be taken by an individual specifically charged by the foreign court or law with such a function. The statutes of Illinois, ${ }^{100}$ Mississippi ${ }^{101}$ and Massachusetts ${ }^{102}$ seem to have embodied such a provision by permitting the deposition to be taken by a "competent person" in the foreign country"103 or by a person authorized to administer oaths under the law of that jurisdiction. ${ }^{104}$ Should the individual who administered the deposition be unacceptable to the local court, it could refuse to admit the testimony when the deposition is returned.105 The ad hoc approach would allow the court to weigh and consider as an evidentiary matter the various circumstances relevant to admissibility in each individual case. ${ }^{108}$

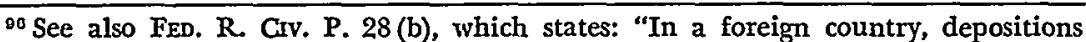
may be taken (1) on notice before a person authorized to administer oaths in the place in which the examination is held, either by the law thereof or by the law of the United States, or (2) before a person commissioned by the court, and a person so commissioned shall have the power by virtue of his commission to administer any necessary oath and take testimony, or (3) pursuant to a letter rogatory."

${ }^{\circ 7}$ This seems to be a common type of provision which is usually included in most statutes. See, e.g., CAL. CIv. Proc. Code § 2018 (b) (Supp. 1965); Del. Ch. CT. R. 28 (b).

${ }^{8}$ E.g., MISS. CODE ANN. $\S 1704$ (1957); VA. CODE ANN. § 8-305 (Supp. 1964); W. VA. CODE ANN. $\S 5735$ (1961). Although a reference to foreign city officials as competent to take a deposition may in some instances allow the United States litigants to comply with the foreign law, it must be remembered that merely because a United States jurisdiction allows a foreign official to take the deposition does not ipso facto guarantee that the procedure of the foreign country involved even contemplates or allows its city officials to perform such tasks.

${ }^{\circ}$ E.g., N.C. GeN. Stat. § 8-71 (Supp. 1965); VA. Code ANN. § 8-305 (Supp. 1964). ${ }^{100}$ ILL. REV. STAT. ch. $110, \S 101.19-2(2)$ (1965). This section is based on FED. $\mathbf{R}$. Civ. P. 28.

101 Miss. CODE ANN. $§ 1704$ (1957).

102 Mass. ANN. Laws ch. 233, $\S 41$ (1956).

103 Ibid.

${ }^{104}$ Il.. REv. STAt. ch. 110, § 101.19-2 (2) (1965); MIss. CodE ANN. § 1704 (1957).

${ }^{106}$ See notes 129-34 infra and accompanying text.

${ }^{100}$ A flexible approach to admissibility will enable a court to consider the need for the particular testimony, the reliability of the person who administered it and the cost in time and expenses to the litigants and court. The trial court should be given broad discretion to weigh probative value against these countervailing factors. See MCCORMICK, EVIDENCE $\S 152$ (1954) for a similar approach regarding relevancy. 
The Uniform Interstate and International Procedure Act's provisions combine several methods embodied in the various state statutes discussed above. Section 3.01 (a) lists a broad variety of persons before whom a deposition may be taken and thus affords a wide variety of possibilities, ${ }^{107}$ all with the purpose of allowing the local litigant to comply with various foreign country requirements. The breadth of the act on this matter is designed to insure that at least one enumerated category of competent commissioners will be acceptable to any given country. ${ }^{108}$

A provision allowing the parties to stipulate to the acceptability of an individual before whom the deposition is to be taken is also a means by which a specific foreign country requirement may be complied with. ${ }^{109}$ Thus, the parties could examine the foreign law, determine an acceptable individual according to such law, and

${ }^{207}$ This section states that depositions may be taken before persons authorized to do so in the place where the deposition is to be taken; before persons authorized under the laws of the United States; before persons commisioned by the local court or by the foreign court pursuant to a letter rogatory; or before a person to which the parties have stipulated. UnIForm InTERstate and International Procedure Act $\S 3.01$ (a).

${ }^{208}$ See Commissioners' Note, 9B Uniform LAws ANn. 94 (Supp. 1965). "The need to accommodate the public policy of many foreign countries makes it desirable to permit as large a group of persons as possible to take examinations." Ibid. The note then points out that the party should carefully scrutinize the law and requirements of the foreign country in regard to commissions since "compulsory process to assist a commissioner is frequently not available in civil law countries. In some instances, the appointment of a judicial officer in the country of examination may obviate any reluctance to permit the execution of the commission or provide compulsory process." Id. at 95 .

Arkansas omits the section of the uniform act pertaining to depositions. However, ARK. Stat. ANN. $\$ 27-2503$ (d) (Supp. 1965), is an adoption of UNiform INTERstate AND International Procedure ACT $\$ 2.04$, which pertains to assistance to tribunals outside the state and the serving of documents for foreign litigants and courts. Uniform Interstate and INTERnational Procedure Act $\$ 2.04$ has also been incorporated into 28 U.S.C. $\$ 1782$ (1964). Oklahoma has adopted the entire act, Okla. Laws 1965, ch. 144, at 168 . The Virgin Islands has, with few exceptions, adopted the entire uniform act. V.1. Cone tit. 5, $\S \S 4901-05,4911-14,4921-22$, 4926.28, 4931-34, 4941-43 (Supp. 1965).

${ }^{200}$ CAL. Crv. Proc. Code $\S 2018$ (b) (Supp. 1965), states that anyone agreed to by the parties may be a competent person before whom a deposition may be taken. It should be noted, however, that it may be dangerous to stipulate to the acceptability of a commissioner who is not competent under the foreign law to take the deposition. See Dorman, California's Statutory Contributions in the Field of International Judicial Assistance, 39 L.A. BAR BuLL. 7, 31 (1963). Statutes such as Louisiana's would ostensibly bar the admissibility of a deposition taken with this infirmity. See notes 93-95 supra and accompanying text.

It may be re-emphasized that deposition by stipulation has often been considered a separate procedure for the taking of depositions. See note 86 supra. However for purposes of this comment, it is viewed as a laudatory provision in a local statute which might afford the litigant an opportunity to comply with foreign requirements. 
stipulate that he be allowed to take the deposition. Several states have provided for such a stipulation procedure, ${ }^{110}$ although a specific statute would not seem to be necessary in view of the wide discretion given the court under modern pretrial discovery procedure. ${ }^{111}$ It would seem that such a rule might be greatly limited by the fact that an adverse party cannot be expected to be overly helpful in obtaining testimony harmful to himself.112 However, if the testimony sought is not known to be vitally detrimental to the adverse party's case and the bar is an ethical one, this objection may be more apparent than real.

\section{Compulsory Process}

An extremely interesting problem is presented by the need to obtain compulsory process within a foreign jurisdiction, ${ }^{113}$ in order to effectuate depositions taken abroad. ${ }^{114}$ State courts generally agree

${ }^{110}$ E.g., Cal. Crv. Proc. Code $\$ 2018$ (b) (Supp. 1965); Mich. Gen. CT. R. 304.2 (3); VA. CODE ANN, $\$ 8.305$ (Supp. 1964). The Michigan rule states that depositions in a foreign country may be taken "before any person upon whom the parties agree by stipulation in writing or on the record." Mrch. GEN. Cr. R. 304.2 (3).

The Virginia provision states that "if the deposition is to be taken in a foreign country, ... [it may be taken] before any person that the parties may agree upon in writing . . . VA. CODE ANN. \$ 8-305 (Supp. 1964).

See also FED. R. Crv. P. 29: "If the parties so stipulate in writing, depositions may be taken before any person, at any time or place, upon any notice, and in any manner and when so taken may be used like other depositions."

112 Wright, Federal Courts \$ 81, at 309 (1963).

${ }^{112}$ Since the limitations on this type of procedure are obvious, these same statutes also provide for the appointment by the court of a commissioner to take depositions. Cal. Civ. Proc. Code $\$ 2018$ (b) (Supp. 1965); Mrch. Gen. CT. R. 304.2 (2); VA. Code ANN. \$ 8-305 (Supp. 1964).

${ }^{113}$ Under letters rogatory, of course, the coercive power of the foreign court is used. It would seem that under rare conditions, the compulsory process of the foreign court might be invoked under a commission also. See DYeR \& SMrTH, op. cit. supra note 84, $\S 598$; notes 87 supra and 140 infra and accompanying text.

The Uniform Interstate and Internatioual Procedure Act does not mention any specific meaus by which the local court might use its coercive power to obtain a deposition abroad, although it does authorize the issuance of letters rogatory under which the process of the foreign court may be utilized. UNIFORM INTERSTATE AND international Procedure Act $\$ 3.01$ (a) (3).

Section 3.02 of the Uniform Interstate and International Procedure Act and $\S 1$ of the Uniform Foreign Depositions Act do concern themselves with local coercive assistance to foreign courts. See notes 89 supra and 114 infra.

114 Although the main body of this comment only concerns itself with the taking of depositions abroad for use within the United States, the local taking of depositions for use abroad also presents an interesting area of study.

The Uniform Interstate and International Procedure Act contains a provision dealing with assistance to be rendered to litigants and courts outside the state. A court of the state "may order a person who is domiciled or is found within this state to give his testimony ... for use in a proceeding in a tribunal outside this state. The order may be made upon the application of any interested person or in re- 
that their coercive power is limited to their own territory. ${ }^{115}$ Certain diverse procedures, however, have been instituted by various

sponse to a letter rogatory and may prescribe the practice and procedure, which may be wholly or in part the practice and procedure of the tribunal outside this state, for taking the testimony ... . To the extent that the order does not prescribe otherwise, the practice and procedure shall be in accordance with that of the court of this [sic] state issuing the order." UNIForm INTERstate and InTERnational ProCEDURE ACT $\$ 3.02$ (a).

The Uniform Foreign Depositions Act which has been rather widely adopted, provides that "whenever any mandate, writ or commission is issued out of any court of record in any other state, territory, district or foreign jurisdiction, or whenever upon notice or agreement it is required to take the testimony of a witness or witnesses in this state, witnesses may be compelled to appear and testify in the same manner and by the same process and proceeding as may be employed for the purpose of taking testimony in proceedings pending in this state." UNIFORM FOREIGN DEPOSITIONS ACT $\$ 1$. For a complete listing of all states having adopted the act, see $9 B$ UNIFORM LAwS ANN. 27 (Supp. 1965). Other states have developed their own generic statutes which treat the problem in much the same manner. See, e.g., ILL. REv. STAT. ch. $110, \S 101.19-8(2)$ (1965); Mass. ANN. LAws ch. 233, $\S 45$ (1956); Miss. Code ANN. § 1885 (1957); N.Y. Civ. Prac. Law § 3102 (e); N.C. Gen. Stat. § 8.84 (1953); Ohio Rev. Code ANN. \$§ 2319.08, .11 (Page 1954); Tex. Rev. Grv. Stat. ANN. art. 3769 (a) (Supp. 1965); Utah R. Giv. P. 26 (g); Wis. STAT. $§ 326.24$ (1963). The United States, in contrast with many civil law countries, see note 90 supra, maintains a rather liberal attitude toward foreign requests for assistance. In the absence of specific statutes to the contrary, neither the federal government nor the states ohject to the taking of voluntary depositions here for use abroad. See McCusker, Some United States Practices in International Judicial Assistance, 37 DeP'T State Bull. 808, 809 (1957). Instances of exception to this general attitude are rare. See Miller, supra note 84, at 1112-14 (1965).

${ }^{115}$ See 8 Wigmore, Evidence $\S 2195$ a, at 89 (MCNaughton rev. 1961). In Solliday v. District Court, 135 Colo. 489, 313 P.2d 1000 (1957), the court asserted that "no state has authority beyond its own borders .... Such recognition as is given our laws or court orders by other states is based solely upon full faith and credit, comity, contract due to uniform acts, or compact." Id. at 497-98, $313 \mathrm{P.2d}$ at 1004. In this case, the Colorado court held that it lacked jurisdiction to compel a corporate official, domiciled in a foreign state, to give a deposition in the foreign court for use in Colorado. This ruling was posited despite the fact that the corporation had brought an action in the Colorado court and it was the defendant in that case who sought the official's deposition. Comment, 9 Orro ST. L.J. 679 (1948). In In re Robbins' Will, 105 N.Y.S.2d 290 (Surr. Ct. 1950), the New York court suggested that it may lack the power to compel a foreign national to take a deposition in his own country since it would have been violative of the foreign country's laws. This latter situation would seem to be the strongest case for holding that the local court lacks jurisdiction. But cf. Note, 63 CoLUM. L. REv. 1441, 1458-65 (1963); Comment, 31 U. CHI. L. REv. 791, 798-99 \& n.29 (1964) (implying that federal courts may require production of documents in violation of the foreign law). The above comment is based upon the assumption that the United States court has jurisdiction over the person ordered to produce. In State ex rel. Walling v. Sullivan, 245 Wis. 180, 13 N.W.2d 550 (1944), the Wisconsin court determined that it had not exceeded its jurisdiction by ordering a non-resident defendant to appear before a notary in his state for purposes of adverse examination. However the defendant had previously appeared generally in the court and had been served with a summons. The court stated that the order "had no extraterritorial effect, in the proper sense of the term." Id. at 189-90, 13 N.W.2d., at 555. But see ILI. REv. STAT. ch. 110, §§ 16-17 (1965) (long-arm jurisdiction statute); Nelson v. Miller, 11 Ill. 2d 378, 143 N.E.2d 673 (1957). 
states in an attempt to solve the enforcement problem. Illinois ${ }^{116}$ and Michigan ${ }^{117}$ have enacted statutes whereby the court may order a non-resident plaintiff to appear at a "designated place" for the purpose of having his deposition taken. ${ }^{118}$ The Michigan rule provides that where "the deposition of a non-resident defendant cannot be taken in the state of his residence, the court may order him ... to appear at a designated place ... for the purpose of having his deposition taken ...."119 Although the legislature's comment accompanying the Michigan rule views the cases of the non-resident plaintiff and non-resident defendant in the same light, ${ }^{120}$ such an approach is not justified. The non-resident plaintiff is the "initiator" of the proceeding; hence, it is not unfair to require him to comply with the procedures of the court system which he has caused to be set in motion. The case of the non-resident defendant is quite distinguishable. He may have no in personam connection with the local court ${ }^{121}$ and an attempt by that court to use its coercive power extraterritorially would seem to be encroaching on the sovereignty of the country where he resides. ${ }^{122}$

\footnotetext{
116 ILL. REV. STAT. ch. 110, § 101.19-8 (3) (1965).

117 Mich. GEN. CT. R. 305.2.

${ }^{128}$ ILI. REV. STAT. ch. 110 \$ 101.19-8 (3) (1965). Mich. GEN. CT. R. 305.2 is almost identical. These statutes appear to be based on federal case law which indicates that in the absence of special circumstances a non-resident plaintiff must make himself available for examination in the forum where the action has been commenced or face dismissal under FED. R. CIv. P. 37 (d). See, e.g., Sullivan v. Southern Pac. Co., 7 F.R.D. 206 (S.D.N.Y. 1947); Producers Releasing Corp. DeCuba v. PRG Pictures, Inc., 8 F.R.D. 254 (S.D.N.Y. 1948), modified, 176 F.2d 93 (2d Cir. 1949) (dismissal on merits modified to provide merely for dismissal).

110 MICH. GEN. CT. R. 305.2.

Note that the statute refers to the deponent's "state of residence." It is not certain whether this information subsumes deponents in foreign countries. This rule authorizes the Michigan court to use its own coercive powers over a non-resident who is in a foreign jurisdiction. It is questionable whether general principles of sovereignty would suffer such a procedure. See generally 8 Wigmore, EvidENCE $\S 2195 a$ (McNaughton rev. 1961).

${ }^{120}$ Committee Comment, Mrch. Gen. CT. R. 305.2 in Rules, Mich. Stat. Ann. at 128 (1964).

${ }_{121}$ The Michigan rule must, of course, be predicated upon the assumption that the Michigan court has obtained jurisdiction over the non-resident defendant or his property. To this extent, then, some slight nexus will by definition be requisite to invocation of the deposition statute. Whether this nexus will be substantial enough to justify an order that the defendant appear for the taking of his deposition will turn upon the adequacy of the connections as gauged by the due process standards of "fair play and substantial justice." "International Shoe Co. v. Washington, 326 U.S. 310, 316 (1945). See WRIGHT, FEDERAL CouRTS $\S 64$ (1963). In an in rem proceedimg involving the property of a foreign resident, the requisite connection is hkely to be absent.

120 See note 119 supra.
} 
A foreign statute itself may provide another means by which the local court can use its compulsory process within the borders of the foreign state or country. Mississippi affords a ready analogy: that state has enacted an unusual provision which allows a foreign commissioner to enter Mississippi and use his own coercive power in order to compel depositions within the state. ${ }^{123}$

An entirely different approach is exemplified by the new federal statutory provision. ${ }^{124}$ It is based upon an assumption that a federal court may be able to effect some sort of compulsory process based on its own coercive power over citizens and residents who are temporarily residing abroad. ${ }^{225}$ There would appear to be no constitutional limitations on the adoption by a state of the federal-type rule in order to compel its own citizens and residents to either submit to a deposition within the foreign country or, where the foreign country forbids this, to travel to a country nearby where such procedure would be accepted. ${ }^{126}$ As with the federal rule, failure to comply would lead to a contempt of court citation as well as attachment and sale of property to satisfy the contempt judgment. Even assuming that a state has no such statute, it may still be possible for the state court to invoke the federal court procedure. For

${ }^{123}$ The Mississippi provision is unusual in that it gives "any commissioner . . . appointed by any court without the limits of this state, to take the deposition of any witness residing or being in this state, ... power to issue subpoenas for the witness to be examined ...." Miss. Cone ANn. $\$ 1885$ (1942).

12428 U.S.C. $\$ 1783$ (a) (1964) states that "a court of the United States may order the issuance of a subpoena requiring the appcarance as a witness hefore it, or before a person or body designated by $i t$, or a national or resident of the United States who is in a foreign country ... If the court finds . . that it is not possible to obtain his testimony ... in any manner." Under a recent amendment, the federal statute has expanded the previous law, held constitutional in Blackmer v. United States, 284 U.S. 421 (1932), to include in its purview instances wherein the deposition is necded in a civil action. 28 U.S.C. $\$ 1784$ (d) (1964) provides for attachment of the witnesses' property within the United States in order to satisfy the contempt finding.

${ }^{125} \mathrm{~A}$ citizen's duty to testify in his country's courts continues while he is abroad. Skiriotes v. Florida, 313 U.S. 69, 73 (194I) (dictum); Blackmer v. United States, supra note 124; WrGMORE, EvIDENCE $§ 2195 \mathrm{c}$, at 102 (McNaughton rev. 1961). It would seem that the states may have an analogous porver with regard to their citizens. Cf. Milliken v. Meyer, 311 U.S. 457, 463 (1940): "As in case of the authority of the United States over its absent citizens ... [Blackmer v. United States, supra note 124], the authority of a state over one of its citizens is not terminated by the mere fact of his absence from the state." It may, however, be questionable whether this state power would extend to absent citizens located in foreign countries rather than sister states.

${ }^{126}$ But see 8 Wrgmore, Evidence $\S 2195 \mathrm{c}$, at 101 (McNaughton rev. 1961), who suggests that a United States court may notify a citizen to appcar for a deposition and if he fails to appear may punish him for contempt, but that United States court order or subpoena to the citizen within a foreign jurisdiction would be considered an intrusion on the jurisdictional sovereignty of the foreign country. 
example, the state could perhaps issue a letter rogatory to the federal court requesting the latter to compel witnesses to testify by invoking the federal long-arm statute. ${ }^{127}$ Should this circuitous method be employed, any violation of the federal order would be a violation of the federal law, and the federal statute's coercive measures would be used against the unwilling deponent. ${ }^{128}$

\section{Procedural Safeguards in Deposition Practice}

Although a foreign court may allow a deposition to be taken within its borders, the deposition may have been taken, by necessity, under circumstances not in accord with the normal procedure required by the local court. ${ }^{129}$ Several trial courts have realistically

${ }^{127}$ It is questionable whether such a suggestion would be permissible under 28 U.S.C. $\$ 1781$ (1964). It might be argued that the statute by implication precludes the contemplated action since it nowhere specifically sanctions such a procedure. It specifically provides that the Department of State is empowered to transmit letters rogatory from courts in the United States to foreign tribunals and to transmit foreign letters to courts in the United States. 28 U.S.C. $\S 1781$ (b) (1964) states that the statute does not preclude the direct sending and receiving of letters by the courts in the United States. However, there is no allusion to any procedure which contemplates the use of letters rogatory between state and federal courts. 28 U.S.C. $\$ 1783$ (1964) does not, however, mention that the subpoena will be issued only if the witness' testimony is needed in a federal proceeding. Thus, the suggestion in the text would seem not to be precluded by the federal statute.

It may be argued in favor of the proposal that state and federal courts are "foreign" to each other with regard to their respective jurisdictions and if the issuance of letters rogatory is an inherent power of a court, see note 138 infra and accompanying text, there is no objection to the sending of a letter rogatory from one foreign court to another.

${ }^{128}$ It is interesting to note that if the proposed procedure were allowed, it could result in a situation wherein the federal court would be using its compulsory process to aid in litigation over which it might not legally have been given jurisdiction. Hypothesize a situation where both parties to a suit based on local law are citizens of the same state and one of the parties attempts to use the procedures suggested in the text. Given the nature of letters rogatory, see text accompanying note 87 supra, the federal court would be using its compulsory process to aid parties in an action over which the federal courts have not been given jurisdiction. In such a situation, use of federal process by a state court through the device of letters rogatory might well be violative of due process.

A problem ancillary to obtaining effective coercive power over the deponent is a means by which the perjured statements of deponents made in a foreign jurisdiction may be punished. 18 U.S.C. $\$ 1621$ (1964) may be a harbinger of future state legislation in this field. This federal statute provides for the punishment of perjured statements whether "made within or without the United States." Ibid. (Emphasis added.)

${ }^{120}$ In order to comply with certain foreign requirements such as the mode of questioning or the person allowed to administer the oath, a commissioner administering a deposition abroad may have to alter the standard procedure which obtains in local courts. If the deposition were taken under a letter rogatory, the procedure used would be that of the foreign court, Commissioners Note to the Uniform Interstate and International Procedure Act, 9B UNIForm LAws ANN. 94, 96 (Supp. 1965), and the chance of an inconsistency between the local procedure and the procedure 
held that certain procedural inconsistencies will not be sufficient to exclude the introduction of such depositions at the trial.130 This type of liberal, discretionary procedure would seem to be imperative when dealing with divergent legal systems. If strict local evidentiary requirements were applied to a deposition obtained abroad, the amount of evidence ultimately admitted at trial might be so small as to be of little value. A salutary procedure has been codified by Massachusetts, whose statute provides that depositions taken in foreign jurisdictions under procedures at variance with local practice may be admitted into evidence at the court's discretion. ${ }^{131}$ The Uniform Interstate and International Procedure Act contains a similar provision. ${ }^{132}$

Liberality in admission of foreign depositions would appear to be concomitant with the need to relax procedural requirements in order to facilitate the taking of depositions abroad. As an integral part of the decision to admit the deposition, the local courts apply a standard of relevancy.133 A court should also weigh the reliability of the deposition under the circumstances. The relevance is often at issue before the deposition is returned as a factor in the decision to issue a commission or a letter rogatory, although the standard of relevance for admission of the deposition is necessarily higher. ${ }^{134}$

under which the deposition was taken would be greater. "In cxecuting a letter rogatory, the courts of other countries may be expected to follow their customary procedure for taking depositions. In many non common-law countries, the judge questions the witness, sometimes without first administering an oath, attorneys put any supplemental questions, either to the witness or through the judge, and the judge dictates a summary of the testimony, which the witness acknowledges as correct." Id. at 96.

${ }^{130}$ E.g., In re Derinza, 229 Mass. 435, 118 N.E. 942 (1918); Tyng v. Thayer, 90 Mass. (8 Allen) 391 (1864); Gersten v. Schroder Trust Co., 261 App. Div. 934, 25 N.Y.S.2d 461 (1941); see Commissioners' Note to the Uniform Interstate and International Procedure Act, supra note 129, at 96. A liberal modicum of discretion should be left to the trial judge in order to permit the local court to refuse to admit testimony "taken under circumstances indicating that it is entitled to little credence . . . " Ibid. This discretionary power is embodied in UNIFORM INTERSTATE AND INTERNATIONAL Procedure Acr \$ 3.01 (b). See note I32 infra.

131 Mass. ANN. Laws ch. 233, \$ 44 (1956).

132 "Evidence obtained in a foreign country in response to a letter rogatory need not be excluded merely for the reason that it is not a verbatim transcript or that the testimony was not taken under oath or for any similar departure from the requirements, for depositions taken within this state." UNIFORM INTERSTATE AND International Procedure Act \$ 3.01. The federal rules also contain a similar provision. Fed. R. Grv. P. 28 (b). See generally Miller, supra note 84, at 1094-95 \& n.79.

${ }^{133}$ See note 130 supra. This admission procedure would scem to be subject to the usual discretionary powers given trial courts under the rules of evidence. See gen. erally McCormick, EVIDENCE § 152 (1954).

${ }^{134}$ A court may apply a lesser standard of relevancy before it issues a commission or a letter rogatory. See, e.g., Kustka v. Belmont Terrace Holdings, Inc., 234 App. 


\section{B. LetTERS ROgatory}

Even if the local deposition statute is drawn as broadly as possible, it may still be unwieldy in certain circumstances. The jealous nature of sovereignty exhibited by some of the civil law countries may, in effect, negate the effort of the domestic statute to obtain flexibility. ${ }^{135}$ In addition, local statutes have not as yet been able to deal effectively with the problem of the involuntary deponent located in a foreign country or with the deponent who makes perjurious declarations.

Letters rogatory may provide a solution to these problems. Such letters are requests for coercive assistance sent by the local court either directly to a foreign court or to a foreign government from whence they are transmitted to the corresponding foreign court. ${ }^{130}$ When letters rogatory are employed, the procedure used in taking the deposition will be that of the foreign court. ${ }^{137}$ Issuance of letters rogatory has been considered an inherent judicial power ${ }^{138}$ and it thus is quite possible that statutory authorization is not required.

It is obvious that since the procedure used under letters rogatory is governed by the rules of the foreign court, ${ }^{139}$ the local litigant's

Div. 713, 252 N.Y. Supp. 840 (1931); Goshi Kaisha Yamamoto Sohonten v. France \& Canada Steam Ship Co., 196 App. Div. 551, 188 N.Y. Supp. 131 (1921). A state statute may also reuire "sufficient cause" before a commission will be issued to take evidence out of state. See, e.g., Wis. STAT. ANN $\S 326.26$ (1958).

A returned deposition will be more carefully scrutinized with regard to relevancy. In addition, local courts often question the procedure used by the foreign court or commissioner in obtaining the deposition. See, e.g., Tyng v. Thayer, 90 Mass. (8 Allen) 391 (1864); Gersten v. Schroder Trust Co., 261 App. Div. 934, 25 N.Y.S.2d 461 (1941); Tomaka v. Pennsylvania R.R., I3 Misc. 2d 272, 177 N.Y.S.2d 858 (Sup. Ct. 1958); La Greca v. Giaquinta, 129 N.Y.S.2d 565 (Sup. Ct. 1954); Ecco High Frequency Corp. v. Amtorg Trading Corp., 196 Misc. 405, 94 N.Y.S.2d 400 (Sup. Ct. 1949); In re De Lowe's Estate, 143 N.Y.S.2d 270 (Surr. Ct. 1955). See also Comment, 9 Оноо ST. L.J. 679 (1948).

${ }^{135}$ See note 90 supra.

${ }^{130}$ See generally Doyle, supra note 91, at 37; authorities cited note 87 supra. Various states have a provision regarding letters rogatory. See, e.g., CAL. Civ. Proc. Code $§ 2018$ (Supp. 1965); Colo. R. Civ. P. 28 (b), (d); N.Y. Crv. Prac. LAw §§ 3108, 3113 (a) (3). 28 U.S.C. $\S 1781$ (1964) allows the United States Department of State to receive and transmit letters rogatory to and from foreign countries. This facilitates a procedure which has, in the past, been hampered by impediments imposed by the State Department. H. Jones, International Judicial Assistance: Procedural Chaos and a Program for Reform, 62 YALE L.J. 515, 562 (1953).

${ }^{137}$ See In re Kadar's Estate, 6 Misc. 2d 650, I62 N.Y.S.2d 411 (Surr. Ct. 1957); note 129 supra. See generally authorities cited note 87 supra.

${ }^{138}$ See, e.g., In re Martinelli, 219 Mass. 58, 106 N.E. 557 (1914); Decauville Auto. Co. v. Metropolitan Bank, 124 App. Div. 478, 485, 108 N.X. Supp. 1027, 1033 (1908); 8 WigMore, Evidence $\S 2195 \mathrm{a}$, at 92 (McNaughton rev. 1961).

${ }^{130}$ See In re Kadar's Estate, 6 Misc. 2d. 650, 162 N.Y.S.2d 411 (Surr. Ct. 1957); note 129 supra. 
request, if honored by the foreign court, is assured of complying with that court's requirements. The problem of the involuntary deponent may also find its solution in the letters rogatory procedure. Because of the nature of the proceeding, the foreign court may use its compulsory process and require the deponent to appear before the court and give his testimony. ${ }^{140}$ For the same reasons, it would seem that the foreign court could apply sanctions to a witness who has given perjured testimony.

Letters rogatory thus provide an excellent procedure for the taking of depositions abroad. However, certain drawbacks do become evident. Although some courts and commentators consider letters rogatory cumbersome ${ }^{141}$ or undesirable, ${ }^{142}$ the major diffculty would seem to arise when the deposition thus obtained is offered for admission in the local proceeding. Since, under a letter rogatory, the foreign court will quite definitely adhere to its own procedural rules, ${ }^{143}$ the local court may be faced with the problem of either admitting testimony obtained under evidentiary practices foreign and possibly antithetic to the local court or excluding testimony which may be an integral part of the litigant's cause of action. Again, liberal rules of admissibility will be requisite to a viable utilization of this procedure. ${ }^{144}$

Additional problems may also present themselves: the foreign court may simply refuse to execute the letter; the foreign court may not have a procedure for compulsory process in such a situation; or the foreign court may be burdened by the fact that it will have to inquire into the relevance and justice of the evidence sought in order to protect its own citizens or persons resident under its jurisdiction.

\footnotetext{
${ }^{140}$ See generally Doyle, supra note 91 , at 37; Commissioners' Note to Uniform Interstate and International Procedure Act, 9B UNuForm LAws ANN. 94, 95 (Supp. 1965); authorities cited note 84 supra.

1 141 Note, 96 U. PA. L. REv. 241, 249 (1947).

${ }_{142}$ La Greca v. Giaquinta, 129 N.Y.S.2d 565, 567 (Sup. Ct. 1954). Professor Wigmore also points out that the use of letters rogatory may present problems since it may often be quite difficult to determine the appropriate foreign court, obtain accurate information concerning its procedures and specific jurisdictional limits and receive assistance with the linguistic problems involved in making such a request of a foreign court. 8 WIGMoRE, EvidencE $\$ 2195 \mathrm{~b}$, at 94 (McNaughton rev. 1961). It would seem that the unfavorable light in which letters rogatory have sometimes been characterized may be due to the fact that the local court is forced to give up a good deal of control over the deposition when it is taken. In re Kadar's Estate, 6 Misc. 2d 650, 162 N.Y.S.2d 411 (Surr. Ct. 1957); note 129 supra.

${ }^{143}$ See note 129 and text accompanying note 137 supra.

14 See notes 129-34 supra and accompanying text.
} 
Recognizing the various advantages ${ }^{145}$ of letters rogatory, section 3.01 of the Uniform Interstate and International Procedure Act authorizes this issuance. The act emphasizes that the letters should be issued liberally, and the litigant need not show that all other measures are impractical. ${ }^{146}$ It is specifically provided that the request for assistance from the foreign court must be issued through the local court and not by an individual acting on his own behalf.147 Foreseeing the problem which the local court may face upon return of the executed letter rogatory, ${ }^{148}$ the act specifically authorizes the local court to admit a deposition obtained under circumstances not fully coterminous with local procedure. ${ }^{149}$ The act also contains provisions authorizing a local court to honor any letters rogatory from foreign courts. 150

\section{ConcLusion}

It would seem that under current conditions, viable statutes for the taking of depositions abroad must contain provisions relating to both letters rogatory and deposition by commission, and the Uniform Interstate and International Procedure Act affords an excellent model in this regard. This eclectic approach will enable the local court to treat various situations as effectively as possible. Where a foreign court will allow a deposition to be taken by commission, the local court, since deposition practice is greatly facilitated, may exercise a greater degree of control over the proceedings in the foreign country. ${ }^{151}$ If the commission procedure is not allowed and the witness will not voluntarily tender his statement, letters rogatory provide the most feasible answer. The local court might be in a better bargaining position, both with regard to a foreign court's allowance of a deposition within its borders and with regard to requests for the execution of letters rogatory, if some sort of reciprocal requirement were included in the local statute. ${ }^{152}$ Such parochialism could, however, create unnecessary hostility by foreign

\footnotetext{
140 See notes 139-40 supra and accompanying text.

140 Uniforar Interstate and International Procedure Act $\$ 3.01$ (b).

117 Uniform Interstate and International Procedure Act $\S 3.01$ (a) (3). Contra, MICH. GEN. Cr. R. 305.3, which specifically contemplates a direct request for assistance to the foreign court from the local litigant.

${ }^{148}$ See notes 129-34 supra and accompanying text.

160 Uniform Interstate and International Procedure Acr $\$ 3.01$ (b).

150 Uniform Interstate and International Procedure Act $\$ 3.02$. See notes 113-14

${ }^{15 x}$ See notes $142-43$ supra and accompanying text.

${ }^{152}$ See, e.g., VA. CoDE ANN. $\$ 8-316.2$ (Supp. 1964); Wis. Stat. ANN. $\$ 326.24$ (1958).
} supra. 
courts which may be bound to some extent by statutory strictures. Thus, the initial step toward international judicial assistance should perhaps be undertaken by negotiating bilateral treaties governing deposition practice. ${ }^{153}$

${ }^{153}$ See 8 Wigmore, Evidence § 2195 (b) (McNaughton rev. 1961); Note, 96 U. PA. L. REv. 241, 254 (1947).

In answer to the argument that state procedure would not he aided by bilateral treaties on a national level, Professor Jones points out that "it is doubtful that it would be argued today that the benefits of procedural reform must be denied the state courts in the international field where the states themselves are powerless to act," since a United States treaty would also be the law of the states, U.S. ConsT. art. VI, $\S 2$. H. Jones, supra note 136, at 562. However, it should be noted that although the treaties of the United States become binding upon the states, U.S. CONST. art. VI, $\S 2$, there is no guarantee that a foreign country will render assistance to the states if it has only agreed to cooperation with the United States. Such a treaty should specifically provide that the states may avail themselves of the assistance of the foreign signatory. 